\title{
PASTOS COMUNES O CERCADOS EN EL REINO DE GRANADA. UNA CUESTIÓN A DEBATE A FINALES DEL ANTIGUO RÉGIMEN*
}

\author{
por \\ FELIPA SÁNCHEZ SALAZAR \\ Universidad Complutense de Madrid
}
RESUMEN: El presente artículo tiene por objeto contribuir a una temática escasamente tratada por la bistoriografía: los cercados de tierras y la privatización de las bierbas en Es- paña. Trato de acercarme a esta cuestión a través del análisis de una polémica que tuvo lugar en el reino de Granada sobre la pertenencia de los pastos que producían las propiedades privadas cuando no estaban sembradas. Controversia a que dio lu- gar la legislación del reinado de Fernando VII, contrapuesta a la dada por los Re- yes Católicos a este reino tras la conquista. Se cuestionaba si las leyes del siglo XV seguían vigentes en 1826-1827.

Palabras clave: Pastos comunes o privados. Mesta. Reino de Granada. Antiguo Régimen.

ABSTRACT: This article aims to study a subject that has been little addressed in the bistoriography: the enclosure of land and the privatization of pasture land in Spain. The intention is to approach this question throught the analysis of a muchdebated problem that took place in the kingdom of Granada concerning the ownership of common pastureland and privately-owned, non-arable properties. The regime of Fernando VII legislated against the existing laws of the Catbolic monarchs, established after the Reconquest; it was widely questioned in 18261827 wether the laws of the fifteenth century remained valid.

KeY WORDS: Enclosures. Pasture. Mesta. Kingdom of Granada. Ancien Regime.

* El presente trabajo forma parte del proyecto de la DGICYT PS 95-0197 sobre "Relaciones entre la Mesta y el mundo agrario".

Hispania, LXII/3, núm. 212 (2002) 957-992 
El presente artículo tiene por objeto contribuir a una temática escasamente tratada por la historiografía: los cercados de tierras y la privatización de las hierbas en España ${ }^{1}$.

Trato de acercarme a esta cuestión a través del análisis de una polémica que tuvo lugar en el reino de Granada en razón de si los pastos que producían las heredades privadas, cuando no estaban sembradas, pertenecían a sus dueños o eran comunales. Controversia a que dio lugar la legislación del reinado de Fernando VII, contrapuesta a la dada por los Reyes Católicos a este reino tras la conquista.

Sobre este asunto se pronunciaron particulares, municipios, instituciones y tribunales de justicia a quienes pidió informes el Consejo de Castilla. Esta cuestión, como afirmaba la Chancillería de Granada, interesaba a todos los habitantes de este territorio por afectarles las leyes del siglo XV. Se cuestionaba si éstas seguían vigentes en 1826-1827.

\section{ANTECEDENTES HISTÓRICOS Y JURÍDICOS}

La amplitud de territorios ocupados por los cristianos en el proceso de reconquista, en los que abundaban los bosques, montes, eriales, la baja densidad de población y las razzias frecuentes con los musulmanes en zona de frontera facilitaron el auge de la ganadería extensiva ${ }^{2}$. Ésta permitió poner en rendimiento, con poca mano de obra, tierras que de otra forma habrían quedado improductivas ${ }^{3}$.

Los monarcas dotaron a concejos y particulares de terrenos tanto de uso agrícola como exclusivamente ganadero: dehesas, prados, ejidos... Las tierras no repartidas quedaron como baldías, donde los ganados habrían de herbajar libremente ${ }^{4}$. Además, podían pacer en tierras de cultivo en determinadas épocas del año. Recogida la cosecha de cereales, las reses de todos los vecinos podían aprovechar los rastrojos y barbechos. Es lo que se denomina derrota de mieses 5 .

\footnotetext{
1 En Castilla fue objeto del pionero estudio de Jesús García Fernández (1965), pp. 692-718. En versión castellana (1966), pp. 117-131. En Cataluña, Elisa Badosa Coll (1984), pp. 149-162 y Mónica Bosch, Rosa Congost y Pere Gifre (1995), pp. 63-73. En Valencia, Jesús Millán (1984), pp. 112-117, 212-225, Tomás Peris Albentosa (1989), pp. 34-38 y D. Bernabé (1993), pp. 11-77. Vid. también Fermín Marín (1987) y Jerónimo López-Salazar (1987), pp. 46-87. Juan Diego Pérez Cebada en una tesis sobre Jerez de la Frontera, que permanece inédita, ha tratado sobre los cercados; (2001).

2 José María Mínguez Fernández (1982), pp. 341-354; C.J. Bishko (1982), pp.1-49; J.A. García de Cortazar y otros (1985); Ángel García Sanz (1988), p.37; Carmen Argente del Castillo (1991), T.II, pp. 362-364; María Antonia Carmona Ruíz (1998), p.97.

3 Carmen Argente del Castillo (1991), T. II, p. 363.

4 Sobre tierras de aprovechamiento ganadero en la Edad Media, vid. Carmen Argente del Castillo (1991), T. II, pp. 369-400; Mª Antonia Carmona Ruíz (1998), pp. 97-174.

5 Sobre los fundamentos de esta práctica, vid, entre otros, Joaquín Costa (1898), p.506; Gervasio González de Linares (1902), T. II, pp. 407-408; Alejandro Nieto (1959), T. I, pp. 190-191; Jesús García Fernández (1963), pp. 28-39, (1966).
}

Hispania, LXII/3, núm. 212 (2002) 957-992 
Uno de los fenómenos más representativos de la Edad Media fue, según María Antonia Carmona Ruiz, el de las hermandades o comunidades de pasto. Tenían como finalidad la explotación en común entre varios concejos de los terrenos comunales. Podían aprovechar cuanto estos producían: pasto, frutos silvestres, caza, leña, madera, carboneo, aguas, etc. El origen de estas hermandades se remonta al siglo XI, aunque en Andalucía no hay constancia de éstas hasta el XIII. Surgieron por iniciativa real o por acuerdos entre distintos concejos para facilitar la movilidad de los ganados y evitar las tensiones entre diferentes municipios por compartir los pastizales ${ }^{6}$.

También aparecieron en la segunda mitad del siglo XIII o principios del XIV en un número limitado de ciudades, sobre todo andaluzas, unas organizaciones de carácter municipal, denominadas mestas en Castilla y ligallos en Aragón. Su finalidad principal era el control y organización de la ganadería local. Fueron dotadas de poderes ejecutivos, judiciales y legislativos, que los alcaldes de Mesta solían desempeñar. En algunas, como Carmona y Jerez de la Frontera, el control del concejo sobre estas instituciones fue férreo al intervenir en el nombramiento de los alcaldes. Según María Antonia Carmona Ruíz se debió al deseo de quienes componían los ayuntamientos, algunos grandes propietarios de ganados, de utilizar en su beneficio la Mesta municipal. Otras, como la de Sevilla, gozaron de gran autonomía en el nombramiento de los cargos. Los grandes ganaderos eran quienes la controlaban. La importancia y poder que alcanzaron las mestas en Andalucía puede explicar, según esta autora, la escasa significación de la Mesta Real en este territorio ${ }^{7}$.

Hasta el siglo XV la baja densidad de población existente en Castilla determinó que la labranza y cría de ganados se desarrollaran en armonía. Pero en esta centuria el aumento de la población hizo necesario poner más tierras en cultivo. Los pastos empezaron a escasear para una ganadería, tanto estante como trashumante, que estaba en proceso de expansión. Fue entonces cuando se plantearon conflictos entre estas dos actividades económicas que competían por el mismo espacio. Las principales tensiones que surgieron fueron el resultado de la usurpación y rotura de tierras comunales, el cercado de fincas pertenecientes a particulares, que quedaron desafectadas de usos comunales que las gravaban, la formación de nuevas dehesas y ampliación de las existentes, a costa muchas veces de baldíos contiguos. Esos procesos tuvieron lugar, en ocasiones, con permiso de la Corona, los concejos o los titulares de señorío, pero, con frecuencia, de manera ilegal ${ }^{8}$. Ello obligó a los Reyes Católicos a intervenir para

6 De su estudio se han ocupado, entre otros, Manuel González Jiménez (1978); Manuel García Fernández (1989), pp. 329-343; Luis Suárez Fernández (1951), pp. 5-57; Carmen Argente del Castillo (1991), T. II, pp. 440-465; Ma Antonia Carmona Ruíz (1998), pp. 231-265.

7 Vid también Ch. J. Bishko (1978), T. I, pp. 347-375; Manuel González Jiménez (1981), pp. 99-145; Ma Antonia Carmona Ruíz (1998), pp. 355-394.

8 Miguel Ángel Ladero Quesada (1976), pp. 19-91; Emilio Cabrera Muñoz (1978), T. I, pp. 33-83; José Antonio Fernández Otal (1993); Carmen Fernández-Daza Alvear (1993), pp. 89-106; 
atajar estos excesos. Por real orden de 1480 mandaban anular los acotamientos hechos en tierras comunales. Por provisión de 12 de junio de 1502 prohibían hacer nuevas dehesas o ampliar las existentes sin permiso del Consejo Real9.

Muchos municipios adehesaban tierras comunales para reservar los pastos a las reses de los vecinos, impidiendo su uso a los foráneos, ante la escasez de herbajes. Algunos concejos cerraron total o parcialmente sus términos para aprovecharlos exclusivamente, evitando la entrada de ganados de fuera, ya fuese de lugares con los que habían concertado hermandades o trashumantes.

Tampoco faltaron ayuntamientos y particulares que trataron de sacar rentabilidad de las tierras ante la subida del precio de las hierbas. Era el resultado del aumento de la demanda por el crecimiento de la ganadería y de la escasez de pastos de libre disposición. Quienes realizaban adehesamientos de tierras comunales y cercados de propiedades particulares también pretendían arrendar pastos y rastrojos a ganaderos de la localidad o de la Mesta. Este proceso adquirió importancia, sobre todo, en tierras de señorío.

Granada fue el último reino que pasó a poder de los monarcas cristianos en 1492. Este territorio no quedó al margen de los procesos que se estaban desarrollando en los ocupados con anterioridad. Tras la conquista, tuvo lugar un auge de la ganadería ovina ${ }^{10}$ y la llegada de ganados mesteños, sobre todo al N.O ${ }^{11}$. Ello puede explicar que quienes resultaron beneficiados por los reyes con donaciones de tierras trataron de adehesarlas, bien para reservar las hierbas para sus propios rebaños o para alquilarlas a los ganaderos trashumantes.

La actitud de los Reyes Católicos ante los adehesamientos no fue la misma en toda Andalucía. En Córdoba, la oligarquía de la ciudad acotaba sus tierras para arrendar los pastos, mientras que sus ganados aprovechaban gratis los comunales. Los monarcas, en carta fechada el 28 de septiembre de 1490 , poniendo en vigor un antiguo ordenamiento de Enrique II, de $1375^{12}$, permitieron que cualquier propietario de la ciudad adehesara la cuarta parte de sus fincas y sólo la octava parte si se trataba de personas que habitaban en otras poblaciones sometidas a su jurisdicción. No obstante, los abusos cometidos por la oligarquía cordobesa en adehesar obligaron a los reyes a intervenir de nuevo para limitarlos. El 3 de noviembre de 1490 ordenaron que las dehesas acotadas desde hacia treinta años quedasen de pasto común para los vecinos de la ciudad y su tierra ${ }^{13}$.

\footnotetext{
$M^{a}$ Antonia Carmona Ruíz (1993), pp. 51-67; (1995); (1998); Daniel Rodríguez Blanco (1993), pp. 69-88; Carmen Argente del Castillo (1991), T. II, pp. 400-420, 569-622; Pauline Rufo Isern (1997), pp. 465-512; Juan Diego Pérez Cebada (2001).

9 Citadas por Fermín Marín (1987), T. I, pp. 451-453.

10 Constatada por José Ramón Ramos Ibaseta (1988), pp. 158-161.

$11 \mathrm{M}^{\mathrm{a}}$ Antonia Carmona Ruíz (1995), p. 380.

12 Este monarca autorizó a adehesar la cuarta y octava parte de las heredades respectivamente, según que estuvieran en lugares despoblados o habitados y consintió a los propietarios a arrendar los pastos. Carmen Argente del Castillo (1991), T. II, pp. 408, 509.

13 Ibídem, T. II, pp. 587-588.
} 
La actitud de la Corona, a través de los jueces de términos nombrados para poner fin a la usurpación de tierras y otros atropellos en tierra de Sevilla, fue favorable a los dueños de ganados, al mantener todo uso comunal anterior. Pero nunca pudo prohibir los adehesamientos de donadíos y otras propiedades privadas a diferencia del reino de Granada. Los monarcas chocaron con intereses fuertemente arraigados en Sevilla, los de linajes importantes e instituciones poderosas que realizaban los vedamientos. En cambio, en Granada pudieron disponer de mayor margen de maniobra al tratar de organizar una tierra recién conquistada ${ }^{14}$.

La prohibición de adehesamientos en tierras pertenecientes a particulares, en el reino de Granada, tuvo lugar por real provisión de 3 de noviembre de 1490 dada por los Reyes Católicos en Córdoba y el 26 de enero de 1491 en Sevilla. Ésta hacía referencia a que algunas personas a quienes los monarcas habían hecho merced de cortijos y heredamientos en este reino los estaban adehesando, contra las leyes del reino, en perjuicio de los vecinos y moradores, especialmente de los que tenían ganado de labor. Por esta ley prohibían adehesarlos y apropiar los pastos, sin licencia real, porque las hierbas y frutos que naturalmente producían las tierras habían de quedar de pasto común de los vecinos, recogida la cosecha. Quienes contradijeran esta disposición perderían cualquier derecho a las tierras recibidas ${ }^{15}$. Esta ley reconocía la práctica de la derrota de inieses.

Una real provisión, promulgada por los Reyes Católicos en Burgos el 12 de noviembre de 1492, aludía a que «en tiempos pasados» todas las hierbas eran comunes para los ganados de todos los vecinos y moradores del reino de Granada. Por ello podían pastar en distintos términos. No obstante, algunas ciudades, villas, lugares y personas habían procurado eximirse de dicha comunidad y de obtener real provisión para que en sus jurisdicciones no herbajasen ganados de otras. Los soberanos tenían en cuenta que la comunidad de pastos era necesaria y provechosa para la ganadería, la población y «sostenimiento de dicho reino». El beneficio común debía anteponerse al particular. Por ello, ordenaban que todos los términos y tierras del reino de Granada fuesen comunes y que los ganados de los vecinos y moradores de esta zona pudieran pastar en sus propias localidades o en otras. Revocaban cualquier providencia contraria a lo acordado en esta disposición ${ }^{16}$, que aceptaba la comunidad de pastos en este territorio.

Un real despacho de los Reyes Católicos de 18 de abril de 1497, en Burgos, volvía a recordar que los pastos en el reino de Granada era comunes para todos los vecinos ${ }^{17}$.

\footnotetext{
14 Miguel Ángel Ladero Quesada (1976), pp. 26, 40.

15 Está en Novísima Recopilación, ley II, título XXV, libro VII. Jovellanos la analizó en su Informe sobre la Ley Agraria ed. José Láge (1977), pp. 174-175. Proporciona una interpretación errónea de la misma según Francisco de Cardenas (1873), T. II, pp. 292-293.

16 Un ejemplar en Archivo Histórico Nacional (en adelante A.H.N.), Consejos, legajo 3961, núm. 7.

17 Citado por José Ramón Ramos Ibaseta (1988), p. 121.
} 
¿Cuándo se implantó la comunidad de pastos en esta zona? José Ramón Ramos Ibaseta ignora la fecha exacta, pero estima probable que hubiera tenido lugar en los últimos días de marzo o primeros de abril de 1497. La referencia es inexacta, si tenemos en cuenta que el 12 de noviembre de 1496 ya se reconocía por parte de los monarcas. Pero éstos también mencionaban que existía desde antes. José Enrique López de Coca alude a que los Reyes Católicos, «invocando precedentes nazaríes», decretaron la comunidad de pastos en el reino de Granada en enero de 1492, prohibiendo cualquier adehesamiento ¿Cuáles eran esos antecedentes? ${ }^{18}$ Podía tratarse de las mancomunidades de pastos entre diversos lugares cuando este reino estaba en poder de los musulmanes.

Esta institución resultaba beneficiosa para los grandes propietarios de ganado, como el conde de Tendilla, el monasterio de San Jerónimo, el corregidor de la ciudad, entre otros. Pero era lesiva para los repobladores establecidos en la costa porque acentuaba la escasez de hierbas en unos términos exiguos que limitaban su capacidad de disponer de ganado estante y para los concejos que, al ser los pastos comunes, no podrían arrendarlos ${ }^{19}$.

Ante las numerosas quejas de ciudades y villas del reino de Granada contra la comunidad de pastos, los Reyes Católicos delegaron en el arzobispo de Granada, Fray Hernando de Talavera, para que mediase en el conflicto producido. Se conocen las razones esgrimidas por la ciudad de Málaga a este personaje el 6 de agosto de 1499. Exponía, entre otras, que las cláusulas de los repartimientos no recogían la posibilidad de que ganados foráneos penetraran en sus términos; la insuficiencia de los pastizales, si acogían a reses de otros lugares; la pérdida de una posible fuente de ingresos, ya que no podrían alquilar las hierbas; las tensiones que tendrían lugar por la entrada de los rebaños en tierras labrantías; la dificultad de los pequeños ganaderos para criar sus animales fuera de sus pueblos ${ }^{20}$.

Como resultado de estas presiones, los monarcas, por real cédula de 3 de marzo de 1501, abolieron la comunidad de pastos en el reino de Granada, con la salvedad de que ésta se hubiera establecido por mutuo acuerdo de los concejos ${ }^{21}$. En este año, Málaga intentó arrendar los pastizales a ganados foráneos, alegando la falta de ingresos para su mantenimiento. Los reyes no lo consintieron. Por real orden de 18 de febrero de 1502, los soberanos limitaron la afluencia de rebaños a la serranía de Ronda por la insuficiencia de los herbajes ${ }^{22}$.

Los concejos, a través de la redacción de ordenanzas, tendieron a regular las actividades ganaderas. Las de Antequera y Ronda establecían que los rastrojos,

18 José Enrique López de Coca (1985), pp. 196, 216 ha puesto de manifiesto que «La repoblación y reorganización del espacio están presididas por la voluntad de adaptarse a lo que se encuentra, sin hacer tabla rasa del pasado en el plano material».

19 Ibídem, p. 216.

20 José Ramón Ramos Ibaseta (1988), pp. 121-123. La exposición de Málaga es de 1499 y no de 1488 (es una errata del texto).

21 Ibídem, p. 126 y José Enrique López Coca (1985), p. 216,

22 José Ramón Ramos Ibaseta (1988), pp. 129-130. 
recogida la cosecha de cereales, y los pastos fueran de uso comunal para los ganados de todos los vecinos. Por tanto, suponían una defensa de las hierbas frente a las cabañas forasteras. Sólo consentían la estancia durante escasos días a los que iban de paso para herbajar en otras jurisdicciones. No obstante, consta que ganados foráneos, sobre todo de grandes propietarios, pastaban en Antequera ${ }^{23}$.

El reino de Granada también contó con una Mesta municipal ¿Desde cuándo? José Enrique López de Coca refiere que desde mediados del siglo $\mathrm{XVI}^{24}$. Según José Ramón Ramos Ibaseta desde 1520. Se pregunta si esta institución pretendía, con su autonomía, que sus habitantes gozasen exclusivamente de las hierbas de este territorio y oponerse a las injerencias de la Mesta castellana $^{25}$. La referencia que tengo a este organismo es de 1543 . El rey Carlos I, por real provisión de 25 de noviembre de dicho año, autorizaba a la ciudad de Granada a tener una Mesta y aprobaba sus ordenanzas. A éstas se añadieron otras, confirmadas el 6 de julio de $1628^{26}$.

A solicitud de la Mesta granadina, por real provisión de 21 de mayo de 1633, se le concedió que pudiera tener un juez conservador y privativo que habría de ser ministro togado de la Real Chancillería. Lo habrían de elegir quienes integraban esta institución. Este debía guardar y hacer cumplir sus ordenanzas y ejecutorias y proceder contra quienes, en perjuicio de los ganados, las quebrantasen ${ }^{27}$.

La comunidad de pastos debió restablecerse posteriormente. Ignoro cuándo. Es posible que a ello contribuyera la Mesta municipal, a quien beneficiaba que los rebaños dispusieran de pastos gratuitos al desplazarse desde los agostaderos, situados en zonas altas del interior del reino, hasta los invernaderos, ubicados en la franja mediterránea. En 1826, la comunidad de pastos estaba vigente, según refería la Mesta granadina en un memorial dirigido al rey ese año.

En la Castilla de los siglos XVI y XVII fueron frecuentes los litigios que la Mesta Real sostuvo con particulares y concejos porque trataban de obstaculizar la libertad de tránsito y pasto de que gozaban los ganados trashumantes por el reino $^{28}$. Legal o ilícitamente acotaban tierras comunales, rastrojos, barbechos, vides, olivos y otros terrenos, imponían penas y prendas a los ganados por entrar en sitios vedados o por pasar por las jurisdicciones, formaban nuevas dehesas o ampliaban las existentes y cerraban parcial o totalmente los términos para

\footnotetext{
23 Vid. F. Alijo Hidalgo (1974); Antiguas ordenanzas municipales de la ciudad de Ronda y su jurisdicción (1889). Analizadas por José Ramón Ramos Ibaseta (1988), pp. 135-139, 155-158.

24 José Enrique López de Coca (1985), p. 230.

25 José Ramón Ramos Ibaseta (1988), p. 166.

26 Una copia de éstas en A.H.N., Consejos, legajo 3961, núm. 7.

27 A ello aludía la Mesta de la ciudad y reino de Granada en un memorial al rey de 21 de marzo de 1826 , ibídem.

28 Según el privilegio de Alfonso XI de 17 de enero de 1347. Quedaban exceptuados huertos, vides, panes, prados de guadaña y dehesas boyales. De él se ha ocupado Fermín Marín (1994), pp. 72 y sigs
}

Hispania, LXII/3, núm. 212 (2002) 957-992 
impedir la entrada de los mesteños. Fenómenos alentados por la escasez y carestía de los pastos en el siglo XVI debido, por una parte, a las roturas y, por otra, a la demanda de hierbas por el crecimiento de la ganadería en la primera mitad de la centuria ${ }^{29}$.

El verdadero empuje de los acotamientos y creación de dehesas tuvo lugar a raíz del servicio de millones de 1590 . Los monarcas concedieron numerosas licencias a los concejos para acotar y arrendar determinados sitios a fin de facilitar su cobro ${ }^{30}$. Dada la duración de las facultades - 20 a 40 años- y la frecuencia con que se renovaban, los cotos no volvían a abrirse al paso de los mesteños, pues los concejos los consideraban términos redondos para aprovecharse exclusivamente de ellos ${ }^{31}$.

La formación de dehesas en pastos comunes y el acotamiento de las rastrojeras constituyen, según Fermín Marín, dos de los fenómenos más importantes del siglo XVII, sobre todo entre 1625 y 1633 , alcanzando su punto más álgido hacia $1670^{32}$. En el primer caso, pudo ser el resultado de la insuficiencia y alto valor de las hierbas debido a la prosecución de las roturas y en el segundo, habría que preguntarse si se debía a una recuperación de la ganadería ${ }^{33}$ y la necesidad de los vecinos de reservarse los pastos frente a los foráneos.

Quienes realizaban los cercados y adehesamientos pretendían guardar las hierbas a los hatos vecinales o arrendarlas, obstaculizar las migraciones de los trashumantes, evitar la jurisdicción de los alcaldes entregadores, al obligar a las cabañas a cambiar de ruta, poder ejercer las justicias de los pueblos actos de jurisdicción como prendar y multar a los ganados que entraban en sus términos sin permiso ${ }^{34}$. Según Jerónimo López-Salazar, la Mesta logró, en los tribunales, que no se penase y prendase a los rebaños que penetraban en sitios cerrados en

29 M. Caxa de Leruela (1975), pp. 97; Julius Klein (1981); David E. Vassberg (1978), pp. 145-167; (1983); Ángel García Sanz (1980), pp. 95-127; Enrique Llopis Agelán (1980); (1986), pp. 11-37; Jerónimo López-Salazar (1987), pp. 46-57, 111-118; Fermín Marín (1987), T. I, pp. 449-624, T. II, pp. 1085-1210, T. III; Antonio Miguel Bernal (1988) pp. 61-64.

30 Fermín Marín (1987), pp. T. II. p. 1320, 1322, 1399-1484 ha constatado que entre 1500 y 1575 se otorgaron 1 licencia para vedar, 70 entre 1575 y 1590 y 140 entre 1590 y 1600 y para adehesar 3 de 1500 a 1575,76 de 1575 a 1590 y 94 de 1590 a 1600.

Por otra parte, Antonio Miguel Bernal (1988), pp. 61-64 ha puesto de relieve que con motivo de la venta de baldíos en el siglo XVI los compradores de Andalucía intentaban conseguir, al mismo tiempo que la propiedad, el permiso del monarca para cerrar y adehesar. Proceso que culminó, sobre todo, en las fértiles tierras del Occidente andaluz en el siglo XVII. El avance de los cercados y la supresión de aprovechamientos comunales fue más temprano e intenso en pueblos de señorío motivado tanto «por lo que podríamos definir como un concepto moderno de la propiedad burguesa como por razones económicas de aprovechamiento».

31 Fermín Marín (1987), T. II, p. 1087.

32 Ibídem, T. II, pp. 1110, 1144, 1179.

33 Enrique Llopis Agelán (1980).

34 Fermín Marín (1987), T. I, pp. 449-624, T. II, pp. 1085-1210 y Jerónimo López-Salazar (1987), pp. 47, 58.

Hispania, LXII/3, núm. 212 (2002) 957-992 
el Campo de Calatrava, pero no pudo evitar que las cercas se hiciesen y que, en consecuencia, los intrusos tuvieran que abonar el perjuicio causado ${ }^{35}$.

Las oligarquías locales, grandes propietarias de ganados estantes y riberiegos, promovieron los acotamientos para reservar pastos en sus propias jurisdicciones a fin de mantener sus rebaños o alquilarlos, evitando la injerencia de los trashumantes. Los mayores perjudicados eran los pequeños ganaderos que se encontraron con dificultad para mantener sus reses, al restringirles el acceso a pastos gratuitos y estar muchas tierras arrendadas a los mesteños. Este pudo ser el motivo de la lenta recuperación de la ganadería estante en el siglo XVII, al menos en lo referente a los pequeños productores ${ }^{36}$.

Felipe IV, en 1663, tuvo que atender a las demandas de la Mesta ante los abusos de los concejos que, sin licencia, acotaban y cerraban sus términos. Ordenó cumplir el capítulo 28 de la Recopilación que prohibía hacer cotos sin facultad real. En 1669 el Consejo Real volvía a reiterar esta medida, prueba del escaso cumplimiento de la anterior ${ }^{37}$,

Fermín Marín ha puesto de relieve que en zonas de invernadero comunales y rastrojos eran aprovechados, sobre todo, por los ganados estantes mientras que en las de agostadero se arrendaban a los mesteños ${ }^{38}$. Este hecho ha sido constatado por Máximo Diego y Emilio Pérez Romero en tierra de Soria ${ }^{39}$. Desde finales del siglo XV los ayuntamientos procedieron a acotar y arrendar los rastrojos a ganaderos mesteños para paliar el déficit de las haciendas locales.

En el siglo XVIII tanto en tierra de Soria como en jurisdicciones próximas las rastrojeras se habían convertido en agostaderos que los concejos alquilaban, junto a dehesas boyales y prados, a grandes cabañas trashumantes pertenecientes, sobre todo, a vecinos de Soria y de los principales pueblos del Sexmo de San Juán. Así, los ganaderos se aseguraron un control estable y exclusivo sobre estos pastizales, que consolidaron mediante la aplicación a los mismos de la posesión mesteña en el siglo XVII. La ganadería estante, por el contrario, vio reducida su capacidad de mantenerse en zonas cerealistas y se vio desplazada, junto a reses trashumantes de menor entidad, a los baldíos.

En Castilla asistimos, por tanto, a un intenso proceso de privatización de hierbas y rastrojos ¿Qué ocurrió en otros territorios de la monarquía?

En el reino de Valencia, tanto propietarios como señores trataron en los siglos XVI y XVII de convertir sus dominios en dehesas vedadas y de extender a tierras de las que se habían apropiado dicha condición. Ello les permitía disponer de forma exclusiva de hierbas y amprius - cazar, recolectar frutos silvestres, carbonear, recoger cal- Podían impedir la entrada de cualquiera a apro-

35 Jerónimo López-Salazar (1987), p. 47.

36 Así ha sido subrayado por Enrique Llopis Agelán (1986), p. 33.

37 Citado por Fermín Marín (1987), T. II. pp. 1174, 1179.

38 Ibidem, T. II, p. 1127.

39 Máximo Diego Hernando (1993 a), pp. 185-204; (1993 b); (1994), pp. 43-66; Emilio Pérez Romero (1995); (1996), pp. 91-124; (1998), pp. 198-230; (1999), pp. 35-54. 
vechar estos productos, apresar a los ganados y penalizar el allanamiento de sus dominios. Dicho proceso contó con la oposición de la ciudad de Orihuela tendente a impedir las usurpaciones más que a recuperar hierbas y amprius ${ }^{40}$.

En Cataluña proliferaron desde del siglo XVI los cercados. Los particulares que desde dicha centuria solicitaron a la autoridad pública la proclamación de bandos para sus tierras no pedían tanto el derecho a cercarlas - que afirmaban haber ejercido siempre - sino el derecho a «multar» y «hacer encarcelar» a quienes no lo respetasen. Conseguir un bando era, de hecho, legalizar el uso «privado de la tierra» ${ }^{41}$.

Los municipios catalanes empezaron a adoptar medidas hacia 1770 para cercar tierras e impedir la entrada de los ganados. Se valieron, para ello, de redactar nuevas ordenanzas con el fin de proteger vides, olivos y huertas de los rebaños, prohibiendo su introducción en las fincas dedicadas a estos cultivos en cualquier época del año. Al mismo tiempo, impidieron a los vecinos coger la leña, la uva de los campos después de la vendimia y las espigas que quedaban en el suelo recogidos los granos. Los cercados contaron con la oposición de los grandes propietarios de ganados, sobre todo en los valles pirenaicos donde la ganadería era la actividad más importante ${ }^{42}$.

En el siglo XVIII, municipios y particulares estaban recurriendo también a acotar y arrendar rastrojos y pastos comunes. Se trata de una centuria de escasez y carestía de las hierbas como resultado de, por un lado, la expansión de los cultivos y, por otro, la fuerte demanda de pastizales por el crecimiento de la ganadería mesteña ${ }^{43}$. De aquí que concejos y particulares trataran de obtener una rentabilidad de las hierbas o de reservarlas en exclusiva para los ganados propios o de los vecinos. Además, asistimos a un avance del derecho de propiedad individual de la tierra a costa de los derechos comunitarios. Pero son escasos los estudios dedicados a esta temática en este período.

La falta de trabajos sobre el reino de Granada no me ha permitido analizar los cambios a que pudo verse sometida la derrota de mieses y la comunidad de pastos desde el siglo XV. También aquí los pastos comunes se hallaban en retroceso como consecuencia de la rotura de terrenos, la expansión del regadío y de cultivos como la vid ${ }^{44}$, el maíz y la patata ${ }^{45}$, los cercados y el alquiler de los rastrojos ${ }^{46}$.

40 Jesús Millán y García Varela (1984), pp. 114-115, 215-223; David Bernabé Gil (1993), pp. 11-77; Tomás Peris Albentosa (1989), pp. 34-47.

41 Monica Bosch, Rosa Congost y Pere Gifre (1997), pp. 65-88.

42 Elisa Badosa Coll (1984), pp. 149-162

43 Vid., al respecto, Enrique Llopis Agelán (1982), pp. 1-101, (1998), pp. 149-197; Pedro García Martín (1988). Este último autor (1988), pp. 246-247 alude a que concejos de León, Asturias, Palencia, Santander y Burgos arrendaban los pastos comunes como agostadero. Este medio constituía uno de sus principales recursos en el siglo XVIII.

44 Jerónimo López-Salazar (1986), p. 208 menciona que los concejos manchegos indujeron a sus vecinos al cultivo de la vid, en parte, para prescindir de servidumbres ganaderas y de comunida- 
Las normas establecidas en cualquier tiempo y lugar no son inmutables. Los ayuntamientos regulaban el uso del terrazgo de acuerdo con sus propios intereses y los de aquéllos a los que realmente representaba. Podían luchar por su permanencia o transformación si así conviniera. Que la comunidad de pastos no era beneficiosa para todas las localidades granadinas quedó de nuevo de relieve cuando los monarcas designaron personas que pusieron en venta tierras que consideraban como baldías.

Así, en 1642, don Luis Gudiel y Peralta, ministro del Real Consejo, fue comisionado para ocupar y vender los terrenos confiscados tras la rebelión de los moriscos. El ayuntamiento de la ciudad de Granada ofreció veintisiete mil ducados para que confirmara la posesión en que estaban los vecinos de las tierras repartidas después de la conquista y expulsión de los moriscos. El consistorio propuso como condición, que le fue concedida, que no se hicieran acotamientos ni se concedieran licencias para hacer dehesas ni adehesar cortijos ni heredades en todo el reino, sino que todo permaneciera de pasto común porque, si éste faltaba, cesaría la cría de ganados en sus estrechos términos. Esta escritura de concordia se firmó el 14 de julio de $1642^{47}$ y fue revalidada por el rey Carlos IV el 28 de marzo de 1794 ¿Influyó en este acuerdo la Mesta local? Es posible, aunque lo ignoro.

En el siglo XVIII también tuvo lugar la venta de baldíos. Lobres, por escritura de transacción aprobada por Felipe V el 5 de septiembre de 1745, compró las tierras que constó usurpadas. Una de las cláusulas de dicho documento hacía referencia a que podía arrendar los pastizales de su jurisdicción y guardar ésta de todos los ganados forasteros. No obstante, las justicias habían permitido que ganados foráneos entrasen en el término entre 1757 y 1776 para establecer sus parideras, en virtud de despachos librados a su favor por el juzgado de la Mesta de la ciudad de Granada ${ }^{48}$. A partir de 1776 el concejo pretendía

des de pasto. El viñedo — en auge en el siglo XVI - suponía «cerrar al ganado, casi a perpetuidad, el pasto de una tierra determinada». Sirvió en esta centuria «para incrementar el sentido de la propiedad privada». Proliferaron las ordenanzas, de mediados del siglo, destinadas a propiciar tanto la expansión de la vid como su salvaguarda de los ganados, mediante las cercas o prohibiendo su entrada a heredades dedicadas a este cultivo.

45 Sobre estas transformaciones en el reino de Granada vid. Felipa Sánchez Salazar (1986), T.II, apéndice VII-1, pp. 780-793 y X-1, pp. 857-861; (1988), p. 64 y Aurora Gámez Amián (1986), pp. 95-125; (1989), pp. 79-98.

46 Como algunos municipios granadinos lo ponían de relieve, según puede verse en este artículo.

47 A.H.N., Consejos, legajo 3961, núm. 7.

48 El capítulo 14 de las ordenanzas de 1628 establecía que los ganaderos pertenecientes a la Mesta podían introducir sus rebaños libremente en este corregimiento y lugares de señorío, sin tener que registrarlos, porque los privilegios concedidos por los Reyes Católicos dejaron «toda esta tierra para pasto común». El capítulo 19 disponía que las parideras y cañadas habían de guardarse desde primero de marzo a mediados de junio «las tierras de cabaña» y desde el uno de octubre hasta finales de febrero «las tierras y majadales». Ibídem. 
que el término quedara excluido de la comunidad de pastos, alegando la escritura de 1745. Efectivamente, en ésta había conseguido imponer la reserva de sus pastos a favor de sus vecinos frente a los forasteros ${ }^{49}$. Ello suponía quedar al margen de la comunidad de pastos y poder aumentar sus ingresos mediante el arrendamiento de las hierbas.

La derrota de mieses y las comunidades de pastos se estaban viendo limitadas en distintos lugares como consecuencia de los cambios que estaban teniendo lugar en el medio rural. Mutaciones que provocaron la resistencia de aquéllos a quienes perjudicaban.

Los monarcas también contribuyeron a restringir los usos comunales al dar licencia a particulares y concejos para cercar y adehesar ${ }^{50}$ y al promulgar leyes autorizando los cerramientos.

Así, Carlos III, por real cédula de 15 de junio de 1788 permitía que propietarios y colonos cerraran perpetuamente tierras dedicadas o que se destinasen a olivos, vides con arbolado, árboles frutales y huertas con hortalizas y legumbres y durante veinte años los montes en los que se pusieran árboles silvestres. El fin de esta ley era la protección de estos plantíos, por lo que se impedía la entrada de los ganados en ellos ${ }^{51}$.

Hasta la segunda década del siglo XIX no se volvió a legislar en lo referente al pleno disfrute de cuanto la tierra produjera por sus titulares. Fue obra de las Cortes de Cádiz. Estas dieron dos decretos en ese sentido. El primero, de 14 de enero de $1812^{52}$, declaraba cerrados y acotados perpetuamente los montes destinados a plantíos, cuyo suelo y arbolado perteneciera a particulares. Estos podían cercarlos y aprovechar sus productos como quisieran. El segundo, de 8 de junio de $1813^{53}$, en su artículo primero, permitía a los propietarios y colonos cercar de forma permanente las fincas rústicas para disfrutarlas exclusivamente y destinarlas a lo que quisieran. Debían quedar libres los caminos, cañadas,

La predilección de los ganaderos de la Mesta granadina por establecer las parideras en tierras de particulares puede deberse, como ha indicado Jerónimo López-Salazar (1986), p. 234 con respecto al Campo de Calatrava, a que obtenían una seguridad en los pastos que no lograrían en los baldíos, donde otros podían anticiparse a aprovecharlos con sus rebaños.

49 Lobres litigaba con la Mesta de la ciudad y reino de Granada en el juzgado de dicha institución desde 1776 a 1782 sobre la pertenencia de los pastos. A.H.N., Consejos, legajo 3961, núm. 7.

50 Sobre peticiones y licencias concedidas para cercar en el reino de Granada y tensiones por este motivo vid. Felipa Sánchez Salazar (2001).

51 En los montes ampliaba el periodo concedido por la ordenanza de dicho ramo de 7 de diciembre de 1748, que era de seis años. Vid. en Novísima Recopilación, ley XIX, título XXIV libro VII. Esta real cédula fue precedida de otras en las que los monarcas prohibían de forma temporal o permanente la entrada de ganados en montes, vides y olivares. Sobre esta legislación y sobre su puesta en vigor en Extremadura vid. Felipa Sánchez Salazar (2002).

s2 En Colección Oficial de las Leyes (1953), p. 122.

53 En Colección de los decretos y órdenes (1820), T. IV, pp. 80-82, decreto CCLIX. Reproducido por Josep Fontana y Ramón Garrabou (1986), pp. 231-233.

Hispania, LXII/3, núm. 212 (2002) 957-992 
abrevaderos, travesías y servidumbres, que eran esenciales para la trashumancia y, por el primero, además la caza y pesca.

La restauración de Fernando VII al trono supuso mantener el statu quo quebrantado por la guerra de la independencia. Los absolutistas anularon la legislación de las Cortes de Cádiz. Las reales cédulas de 13 de septiembre y 19 de octubre de $1814^{54}$ restablecían la real ordenanza de 12 de diciembre de 1748 y las leyes y órdenes que regían en 1808 en lo referente a los «montes comunes, realengos y de propios», quedando en «libertad los de los particulares». Revocaba el decreto de 14 de enero de 1812 y otras disposiciones expedidas después de 1808 ¿Qué se entiende por esa libertad?

La circular enviada a don Bartolomé Muñoz, escribano de la Cámara más antiguo y de gobierno del Consejo de Castilla, de 7 de enero de $1817^{55}$, permite comprender el alcance de esa libertad en los montes privados. En ésta se le refería que el monarca había determinado, a propósito de una solicitud cursada por un vecino de Escovedo de Carriedo (Santander) para cercar un terreno de su propiedad, que, dado que los montes de dominio particular habían quedado excluidos de la conservaduría ${ }^{56}$ y a la libre disposición de sus dueños, el susodicho «en uso de su derecho" podía tener su heredad cercada o abierta, según le conviniera.

Por tanto, las reales cédulas de 1814 permitían a los particulares cercar los montes de su pertenencia y aprovecharlos exclusivamente.

Que el absolutismo suponía una vuelta a la situación anterior quedaba de relieve por otra disposición, la real cédula de 2 de octubre de $1814^{57}$, que restablecía el Concejo de la Mesta «con todas sus facultades, fueros y privilegios», teniendo presente la decadencia de la ganadería trashumante durante la dominación francesa y los ingresos que proporcionaba a la Real Hacienda.

Esta legislación debió de quedar suprimida durante el trienio liberal. Aunque la única referencia que he encontrado al respecto es una circular del ministerio de marina de 5 de mayo de $1820^{58}$ que extinguía el decreto de 13 de septiembre de 1814 y reponía el de las Cortes de Cádiz de 14 de enero de 1812 . El real decreto de 9 de abril de $1820^{59}$ restituía el de 8 de junio de 1813 .

Con el retorno del absolutismo en 1823 debieron anularse las leyes del periodo liberal y ponerse en vigor las promulgadas entre 1814 y 1819. Estas serían las que regirían cuando la Mesta de la ciudad y reino de Granada dirigió al rey un memorial el 21 de marzo de $1826^{60}$. En él le pedía que mantuviera esta institución y sus ordenanzas y que la real cédula de 19 de octubre de 1814 no

54 Se encuentran en Colección de las reales cédulas (1814), núm. 91, pp. 146-147, núm. 113, pp. 186-188.

55 En A.H.N. Consejos, legajo 3961, núm. 7.

56 Por el decreto de 14 de enero de 1812 ya citado.

57 Colección de reales cédulas (1814), núm. 99, pp. 169-170.

58 Colección Oficial de las Leyes (1953), p. 122.

59 Ibídem, pp. 84-86.

60 En A.H.N., Consejos, legajo 3961, núm. 7. 
rigiera en este territorio, sino que se observase el privilegio de pasto común. Tenía en cuenta que en su virtud las hierbas que naturalmente criaban las tierras no pertenecían a los propietarios en Granada sino que eran comunes para el usufructo de los ganados. Estos no podrían sustentarse en un territorio, como el granadino, compuesto en su mayor parte de terrenos montuosos, sierras y pocas zonas llanas donde establecer dehesas ${ }^{61}$. Circunstancias que hacían necesaria la existencia de las hierbas comunales y la libertad que tenían los hermanos mesteños para designar sitios para paridera de sus ganados.

La Mesta consideraba que la real cédula de 1814 no derogaba el privilegio de pasto común, que debía permanecer para:

$\left.1^{\circ}\right)$ la subsistencia de la ganadería que no contaba con dehesas particulares para su cría y albergue.

$2^{\circ}$ ) Evitar la escasez y carestía de las carnes, difíciles de adquirir por unos pueblos que tenían poca riqueza.

$3^{\circ}$ ) Impedir el perjuicio que se causaría a la labranza, que precisaba de los ganados para hacer fructíferas las tierras.

$\left.4^{\circ}\right)$ Evitar la ruina de la Mesta y que Granada llegara a un estado de pobreza con menoscabo de los intereses del rey.

¿Qué privilegio era éste? ¿Era contrario a las leyes vigentes? ¿Éstas derogaban aquél?

En realidad no se trataba de un privilegio sino de la real provisión de 3 de noviembre de 1490 dada por los Reyes Católicos en Córdoba y el 26 de enero de 1491 en Sevilla, a la que ya he hecho referencia. Las tierras que se cercaran, en virtud de las disposiciones que regían en 1826, quedaban al margen de la derrota de mieses y la comunidad de pastos, pero sólo éstas.

El enfrentamiento entre particulares, por un lado, y la Mesta, por otro, estaba servido en el reino de Granada. Los municipios, como se verá en este estudio, no aparecen unidos en la defensa de los usos comunales. La Mesta se acogía a la real provisión de 3 de noviembre de 1490, que consideraba vigente, y a la real cédula de 2 de octubre de 1814 - que no se refería a la Mesta municipal sino a la Real- para hacer valer sus ordenanzas y seguir usufructuando gratis los pastos. Los particulares, en virtud de ley de 19 de octubre de 1814, cerraban o intentaban acotar no sólo los montes sino cualquier tipo de fincas

61 Sobre las características del medio natural, vid. J. Sernet (1956), pp. 93-189; José Enrique López de Coca (1985), pp. 196-199 y Aurora Gámez Amián (1986), pp. 15-21.

A mediados del siglo XVIII, según las respuestas a las preguntas 9 y 10 del cuestionario del marqués de la Ensenada, analizadas por Aurora Gámez Amián (1986), pp. 95-106, las tierras de pasto suponían el 10 por cinto del total de la superficie que comprendían los pueblos granadinos de los que se tienen datos. Además, cerca de la mitad de la extensión de este reino no se cultivaba por inútil por naturaleza o por desidia de sus dueños. Pero ello no presuponía una cabaña importante, salvo en determinados corregimientos.

Hispania, LXII/3, núm. 212 (2002) 957-992 
que les pertenecían para aprovechar las hierbas con sus ganados o arrendarlas. De igual manera procedían algunos municipios con la finalidad de expulsar a ganaderos foráneos de sus términos y conseguir ingresos del alquiler de las hierbas. Además, de los recursos que unos y otros podían obtener de las multas impuestas a quienes entraran en terrenos cercados. Lo que en el fondo se debatía era la propiedad de los pastos. Éstos, ¿eran comunes o privados?

\section{INFORMES DE INSTITUCIONES Y PARTICULARES DE LA CIUDAD DE GRANA- DA SOBRE LA PERTENENCIA DE LOS PASTOS}

El rey remitió el memorial del Concejo de la Mesta del reino de Granada de 21 de marzo de 1826 al Consejo de Castilla para su consulta. Éste pidió, el 16 de mayo de 1826, que el acuerdo de la Chancillería de Granada informase al respecto, oyendo instructivamente al Concejo de la Mesta de este territorio, al ayuntamiento de la ciudad de Granada y a cuantos tuvieran interés en los pastos ${ }^{62}$.

Juan Pablo Gadeo, en nombre del concejo, justicia regimiento, diputados y síndico personero de la ciudad de Granada, refería el 31 de agosto de 1826 que éstos se adherían a la solicitud del Concejo de la Mesta porque la consideraban apoyada en los principios «de la justicia y en la razón particular de conveniencia pública, interesante al Estado y al común de vecinos de esta capital y pueblos de su comarca». Tenía en cuenta:

$\left.1^{\circ}\right)$ que no sólo de pan vivía el hombre sino también de otros productos igualmente necesarios. Los ganados abastecían de carne, leche y queso a las personas y surtían de materia prima, lana, a las fábricas de paños.

$2^{\circ}$ ) las actividades agropecuarias debían ser fomentadas porque en ellas estribaba «la felicidad del Estado».

$3^{\circ}$ ) la estrecha conexión existente entre labranza y cría de ganados. Éstos proporcionaban abono haciendo más productivas las tierras y que las cosechas fueran más abundantes.

$\left.4^{\circ}\right)$ las carnes eran precisas para el sustento de los hombres y escaseaban en el reino. Sería mayor su penuria si los propietarios podían adehesar y acotar sus fincas. Los cercados impedían la libertad en que se hallaban los ganaderos de introducir sus rebaños a aprovechar los pastos comunes, sin causar perjuicio en siembras y plantíos.

$5^{\circ}$ ) en el reino de Granada era necesaria la mancomunidad de pastos teniendo en cuenta que los términos eran estrechos y que apenas había dehesas comunes. Estas eran de escasa superficie y poca utilidad debido

62 Todos estos informes están en A.H.N., Consejos, legajo 3961, núm. 7. Es una documentación voluminosa compuesta de varias piezas. Constituye el soporte de este artículo. No la vuelvo a citar, salvo que me parezca oportuno.

Hispania, LXII/3, núm. 212 (2002) 957-992 
a la naturaleza de los terrenos, montuosos y escabrosos. Las diferencias climáticas hacían precisa la trashumancia de los ganados. Era conveniente señalar las parideras en sitios adecuados porque de ellas dependía la cría y abundancia de ganados.

$\left.6^{\circ}\right)$ la ganadería descendería si faltaba la mancomunidad de pastos y otras provincias habrían de surtir a Granada de carne a precios altos y sólo podrían comerla quienes pudieran costearla.

$7^{\circ}$ ) los propietarios habían adquirido las tierras con este «gravamen», si así podía considerarse la mancomunidad de pastos, desde el tiempo de la conquista de Granada por los Reyes Católicos. Podrían decir los dueños que con los acotamientos no se escaseaban los pastos porque los ganaderos podían tomarlos en arrendamiento. Afirmación cierta. Pero en este caso, los ganaderos tendrían que abandonar esta actividad ante la carestía de los pastos o habrían de repercutir la subida de los costes de producción en el precio de la carne.

Juan Pablo Gadeo estimaba poco justo que a la sombra de un «mezquino y particular interés», que era el que podía reportar al dueño de predios rústicos el alquiler de los pastos, se causase un perjuicio tan general.

José María Palomo, en nombre del Concejo de la Mesta de la ciudad y reino de Granada, pedía el 20 de octubre de 1826 que subsistiera «el privilegio de pasto común» concedido por los Reyes Católicos en 1490. Desde aquella época, la hierba que criaba la tierra no pertenecía a los dueños de las fincas porque era comunal. Consideraba como un despojo conceder su uso sólo a los propietarios.

El Concejo de la Mesta era el encargado de que se cumpliese y conservase dicho privilegio, sin el cual era imposible la cría de los ganados. Estos eran necesarios para el fomento de la labranza y provisión de carne, leche, queso y lana, que no podrían lograrse con la abundancia que necesitaba un reino tan extenso.

Ese privilegio había sido sostenido por el Real Consejo cuando aprobó las ordenanzas de la Mesta y los tribunales habían mandado que se guardase y observase. Ponía como ejemplo de su acatamiento distintas providencias dadas por el juzgado de dicha institución desde 1757 a 1804 . Este había librado despachos a favor de los hermanos de la Mesta para establecer redondas en sitios señalados para paridera y pasto de sus rebaños y había mandado que las veredas, majadas, descansos y aguaderos roturados en varias localidades se repusieran a su anterior estado.

José María Palomo estimaba que era conveniente la mancomunidad de pastos en el reino de Granada, dada su situación local, y la incapacidad de señalar cotos y dehesas para sustento y albergue de los ganados y facilitarles sus parideras. Creía que sería incalculable el daño que padecería la ganadería si se impedía el pasto común. La importancia del privilegio era incomparable con el corto interés de algunos hacendados que querían acotar y adehesar sus posesio- 
nes para arrendar los pastos, sin considerar la ruina general que habría de originar dicha medida. El interés particular debía posponerse al bienestar de todo el reino. Concluía que mientras se había respetado el privilegio de pasto común habían prosperado tanto la agricultura como la ganadería.

Francisco Antonio Gómez, en nombre del marqués de Villadares y de la Vera, exponía el 7 de mayo de 1827 que todo cuanto contra la Mesta habían alegado ilustrados como Campomanes, Floridablanca y Jovellanos, y en parte había sido remediado por las provisiones del Consejo de Castilla, era extensible a la Mesta particular de la ciudad y reino de Granada. Ésta pretendía aprovechar gratuitamente todos los pastos ajenos «haciéndolos de su propiedad, como baldíos, y de tierras abiertas o incultas».

Opinaba que la Mesta se erigía en opresora de los pueblos, hacendados y labradores dado que «la fuerza está donde el dinero, y éste donde se reúnen muchos que lo tienen, a hacer causa común». Además contaba con sus propios tribunales y con el apoyo del ayuntamiento de la ciudad de Granada, integrado por algunos hermanos de la Mesta, que coadyuvaba a sus pretensiones en lugar de impugnarlas.

Francisco Antonio Gómez consideraba justo que la ganadería del reino de Granada tuviera privilegios y juzgados para su conservación y aumento, sin perjuicio de terceros. Pero no era equitativo que se sustentara en pastos ajenos, contra «el sagrado derecho de propiedad», ni que los ganaderos señalasen las tierras que deseasen sacando despachos de redonda para paridera, impidiendo a los dueños y vecinos el usufructo de los pastos. Esto resultaba inconciliable con «los principios de justicia» y no era necesario para la cría de los rebaños y fomento de las tierras.

Estimaba el informante que quienes tenían exceso de ganados o los tenían por granjería o negociación no debían utilizar de balde las tierras que no les pertenecían. El ganadero habría de tener el rebaño necesario para sustentarlo en los pastos que produjera su tierra a fin de hacerla más fructífera y habría de comprar las hierbas que precisase. Resultaba tolerable que los ganados de la Mesta se alimentasen en los baldíos y en las fincas que los propietarios no tenían acotadas, por necesidad de la trashumancia, pero no en los predios privados que estaban acotados. Podía permitirse a quienes integraban dicha institución la preferencia en el arrendamiento de dehesas y pastos y el derecho a la tasa de las hierbas, pero gozarlas de balde e impedir que los dueños las aprovechasen y cercasen era "allanar el sagrado derecho de propiedad» porque cuanto la tierra producía pertenecía a su dueño y nadie había de disponer de ello ${ }^{63}$. Los mesteños de Granada habrían de poner sus redondas en terrenos propios o arrenda-

63 Decía: «...la espiga es parte del fruto (de la tierra); y ya lo mismo el rastrojo; por lo cual las costumbres de muchos pueblos de estas Andalucías, y Manchas, son que hasta 15 de agosto, las aproveche el dueño, y después todo el vecindario; y ya porque en otros sean pasto común; y en otros se cerquen porción la suficiente a los ganados del dueño, o labrador...».Ibídem, a ortografía de las citas ha sido actualizada. 
dos, en los baldíos, realengos y comunes, pero sólo en los pueblos donde residiesen. Era contrario a «todo derecho» el establecerlos en tierras de particulares disfrutadas por éstos o por los colonos. Del mismo modo que el ganadero no proporcionaba la carne, piel y lana gratis o más barata a los dueños de las heredades, no había de usufructuar de balde los pastos. Dado que lo que pertenecía a uno no debía ser común a otro. Era útil que las reses de los vecinos de un pueblo pastasen indistintamente en terrenos comunales, pero no las de una jurisdicción en otras, como pretendía la Mesta, valiéndose de la mancomunidad de pastos.

El privilegio de pasto común en el reino de Granada no podía considerarse, según Gómez, como «una ley general en este reino», sino restringido a los terrenos que los Reyes Católicos concedieron por merced a los particulares. Prohibieron adehesarlos y acotarlos y en éstos los mesteños, como vecinos, podrían defender dicho privilegio, pero no en los adquiridos por compra u otro título oneroso. Los monarcas, por otra parte, habían concedido numerosas licencias para acotar y adehesar en este reino, como al marqués de la Corona el 4 de abril de 1827, en conformidad con las leyes de 5 de junio de 1788, 13 de septiembre y 19 de octubre de 1814 y 7 de enero de 1817 . Este caso era idéntico al que ahora se ventilaba contra la solicitud de la Mesta y en favor de la libertad de los dueños de acotar sus fincas y gozar exclusivamente sus producciones. Por otra parte, la ley de 1490, concedida para fomentar los ganados de los vecinos y no en particular de los mesteños, estaba derogada por reales providencias en defensa de la propiedad ${ }^{64}$.

Ante la oposición del marqués de Villadares y de la Vera a la solicitud de la Mesta del reino de Granada, se concedió de nuevo audiencia a ésta el 28 de mayo de 1827. José María Salomo, en su nombre, volvía a insistir en los fundamentos de su pretensión, tratando de desacreditar los alegatos del marqués y de persuadir que eran aparentes y desestimables. El marqués deducía que la Mesta del reino de Granada era nociva y que no debía subsistir el privilegio de la mancomunidad de pastos. Salomo se preguntaba ¿para quién era lesiva? Siempre había habido disputas entre labriegos y ganaderos, y pese a tantas tensiones, el rey por real cédula de 2 de octubre de 1814 restableció el Concejo de la Mesta teniendo en cuenta las ventajas de la cría y fomento de los ganados, que eran indispensables y de primera necesidad en el Estado, y que no era tan perniciosa la institución para la labranza. Por ello, había concedido a los ganaderos los medios de subsistencia que había estimado oportunos y compatibles con la labor y aprovechamiento de los productos de la tierra ${ }^{65}$.

64 Si la ley de 1490, según el marqués de Villadares, había quedado suprimida por otras posteriores (que cita), no podía pretender que los mesteños defendiesen la existencia de pastos comunes sólo en las tierras donadas por los Reyes Católicos a particulares en el reino de Granada.

65 Los privilegios concedidos por los monarcas a la Mesta condicionaban el «régimen agrario de los pueblos situados en los aledaños de las vías pecuarias», según Ángel García Sanz (1985), p. 54. El derecho de posesión impedía modificar el uso de las tierras que tenían arrendadas los ganaderos trashumantes. Las leyes prohibitivas de las roturas y cercados imposibilitaban ampliar e intensi- 
Indagaba sobre el origen de la Mesta particular del reino de Granada y encontraba que estaba en el privilegio de pasto común concedido por los Reyes Católicos en 1490, teniendo en cuenta que era necesario para la cría de los ganados. Si al principio fue limitado a las fincas y heredades provenientes de donaciones y mercedes reales, en 1496 lo ampliaron y generalizaron a todas las tierras y términos del reino de Granada. Consiguientemente, los pastos que naturalmente criaban las tierras, cuando no estaban sembradas, no pertenecían a los propietarios porque eran de común aprovechamiento. La ciudad de Granada era quien había solicitado tener una Mesta considerando que la mancomunidad de pastos debía estar sujeta a reglas y estatutos.

Se quejaba el marqués de Villadares que el privilegio perjudicaba a los hacendados porque les privaba de los pastos que producían sus heredades para que los ganaderos los usufructuasen gratis. Estimaba José María Salomo que el daño no era de la gravedad que suponía para que fuera reclamado:

$\left.1^{\circ}\right)$ porque no se impedía a los dueños disfrutar las hierbas con sus propios ganados y, además, se les concedía preferencia.

$\left.2^{\circ}\right)$ porque los pastos no les pertenecían por ser comunales.

Negaba Salomo algunos de los alegatos del marqués de Villadares:

$\left.1^{\circ}\right)$ que los ganaderos hicieran un tráfico de pura negociación. Éstos eran criadores dedicados a esta actividad tan necesaria, por lo cual se les concedían los pastos y redondas para paridera y procreación de los ganados que, sin este auxilio, perecerían.

$\left.2^{\circ}\right)$ que las reuniones de los hermanos de la Mesta se dirigiesen a formar sociedad de tráfico y comercio. Por el contrario, se encaminaban a procurar la conservación de sus privilegios y a evitar que se hiciesen acotamientos y cercados, como deseaban los propietarios y labradores para arrendar las hierbas.

$\left.3^{\circ}\right)$ que el ayuntamiento de la ciudad de Granada hubiese protegido el privilegio por influjo y prepotencia de los hermanos de la Mesta. Pensaba que había sido por su importancia para la cría de los rebaños. Por ello, la ciudad había solicitado que se estableciera la Mesta en 1543 y que se aprobaran sus ordenanzas. También había concertado con D. Luis Gudiel y Peralta en 1642 los terrenos baldíos y realengos, poniendo por condición el respeto del privilegio de 1490. Aunque no dudaba que en

ficar los cultivos a menos que se obtuviera licencia real para realizarlos. En relación a los privilegios mesteños vid. Julius Klein (1981), pp. 303-377; Ángel García Sanz (1998), pp. 72-83 y Fermín Marín Barriguete (1994), pp. 67-89, (1998), pp. 90-143. La legislación puede verse en Alejandro Nieto (1959), t. I, pp. 197-225; Ángel García Sanz (1985), pp. 55-57; Felipa Sánchez Salazar (1988), pp. 24-44 y Fermín Marín Barriguete (1992), pp. 127-150. 
el ayuntamiento alguna vez había habido ganaderos mesteños no debía creerse que «sólo su influjo, y no la razón» había prevalecido.

Opinaba José María Salomo que se estaba ventilando la subsistencia de un privilegio de interés para todo el reino, en cuya defensa se habían manifestado hermanos de la Mesta, hacendados, labradores y el fiscal del Consejo de Castilla. No debía creerse, por tanto, que era el influjo y prepotencia de los mesteños lo que había vencido "sino el bien público y el interés del común y del Estado», que había sido lo que habían considerado la ciudad y el Consejo de Castilla.

El marqués de Villadares quería limitar el privilegio al pueblo donde residiesen los ganaderos y no a los demás del reino, y a que los hermanos de la Mesta disfruten sólo de la preferencia en el arrendamiento de las hierbas. A ello, Salomo respondía que el privilegio era "amplio y absoluto", concedido por utilidad pública, sin que causase una ruina que exigiera de remedio, ni atacara la propiedad privada, porque en las hierbas no existía. No era lesivo a los propietarios que podían gozar las demás producciones de sus fincas y los pastos en tierras ajenas, por ser comunes.

Las licencias que los monarcas habían concedido para acotar en el reino eran limitadas y no alteraban el privilegio que seguía vigente en tierras abiertas. El permiso concedido al marqués de la Corona para acotar sus cortijos no constituía una regla invariable para la decisión de la solicitud de la Mesta porque se trataba de un caso particular.

La real cédula de 19 de octubre de 1814 no era aplicable a los pastos que en el reino de Granada no eran privados. No había derogado la mancomunidad de pastos en este territorio, que seguía siendo útil y necesaria por el aumento de los ganados, sin detrimento de la labranza, que también había progresado.

El juzgado de la Mesta, según José María Salomo, ordenaba siempre que los ganaderos respetasen las siembras, viñas y árboles. La Mesta no se oponía a que se cercaran los montes y tierras que contuvieran arbolado, pero contradecía la libertad general de todo propietario para apropiarse los pastos y prohibir a los ganaderos su aprovechamiento común, según se había observado durante tres siglos.

En resumen, a favor de los pastos comunes se pronunciaron el Concejo de la Mesta y el ayuntamiento de la ciudad de Granada. No era extraño que éste apoyara la solicitud de la Mesta, dado que algunos capitulares pertenecían a esta institución. Trataban de reforzar su pretensión: $1^{\circ}$ ) subrayando la importancia de las leyes de 1490 y 1496 concedidas por los Reyes Católicos al reino de Granada teniendo en cuenta la escasa superficie de los términos de muchos pueblos, la naturaleza de los terrenos, montes, sierras, sin grandes espacios llanos para dehesas, la insuficiencia de éstas y su poca utilidad. Las condiciones del medio natural habían hecho necesario que los pastor fueran comunes para la cría de los ganados y hacían preciso que conservaran esta naturaleza. En virtud de dicha legislación las hierbas que producían las heredades privadas cuando no estaban sembradas no pertenecían a los dueños, sino que eran comuna- 
les. Constituiría un despojo privar a la colectividad de un aprovechamiento gratuito para beneficiar a los propietarios. $2^{\circ}$ ) Resaltaban la importancia de la ganadería en cuanto suministradora de alimentos, de materias primas, la lana, para la elaboración de paños, y de estiércol para hacer más productivas las tierras. Además, constituía para las familias campesinas un medio de obtener rentas complementarias. De ahí que defendieran la legislación del siglo XV que consideraban indispensable para el sustento de los ganados. Pensaban que éstos descenderían si se privatizaban las hierbas. Se equivocaban. Esto no tendría lugar, si los propietarios mantenían la distribución del terrazgo en hojas y no introducían nuevos cultivos en la rotación y, optaban por arrendar los pastos que produjeran. Sólo disminuirían los beneficios de los ganaderos, al aumentar los costes de producción. En lo sucesivo tendrían que pagar por unos pastizales antes gratuitos. Eso es posiblemente lo que más les preocupaba, aunque no lo confesaban. Concluían que el beneficio de los titulares de fincas rústicas, consistente en arrendar las hierbas, debía posponerse al bienestar que reportaba al reino la subsistencia de las leyes promulgadas por los Reyes Católicos.

El marqués de Villadares y de la Vera, como gran propietario, tenía un concepto de la propiedad distinto. Para él la propiedad era plena y, por tanto, cuanto la tierra producía pertenecía a sus dueños. Pensaba que no era justo que los ganados se sustentaran de balde en heredades ajenas, y que los ganaderos mesteños señalaran en fincas privadas los parajes que deseaban para paridera de sus rebaños. Constituía un atentado al derecho de propiedad, al privar a los propietarios del uso de los pastos. Los ganaderos habrían de sustentar sus reses en tierras propias o arrendadas.

El marqués consideraba que era tolerable que los ganados de quienes pertenecían a la Mesta pastasen en baldíos y en predios rústicos de particulares que permanecieran abiertos; que los ganaderos trashumantes tuvieran preferencia en el arrendamiento de dehesas y que gozasen del derecho a tasar las hierbas y que pudieran elegir sus parideras en terrenos de su pertenencia o en los que arrendaran, en baldíos, realengos y comunes en los pueblos donde residiesen. Estos eran los límites que el marqués establecía a las prerrogativas mesteñas. Por otra parte, los ganados de los vecinos de un pueblo podrían sustentarse en los terrenos comunales que hubiese en el término pero no en otras jurisdicciones, lo que implicaba derogar la mancomunidad de pastos.

Las disposiciones del siglo XV, para el marqués de Villadares, eran lesivas a los propietarios porque les impedían disponer de las hierbas. Efectivamente, no podían usarlas de modo exclusivo con sus ganados ni obtener una ganancia arrendándolas. Para la Mesta esto no resultaba tan grave, porque los pastos eran comunes, por tanto no pertenecían a los dueños, tenían preferencia sus ganados para usufructuarlos y, además, podían aprovechar de balde las que producían los predios ajenos.

¿Era correcta la interpretación que proporcionaban de la legislación del siglo XV y de las leyes de 1788 y 1814 ? 
El marqués de Villadares opinaba que la real provisión de 1490 era restringida a los cortijos y heredades que los Reyes Católicos concedieron a particulares y no extensiva a todas las tierras del reino de Granada. La Mesta sostenía la misma versión, pero consideraba que la ley de 1496 había ampliado a todo ese territorio lo estipulado en 1490 .

La primera no establecía una condición aneja a los repartos de tierras realizados tras la conquista. Hacía alusión a las leyes del reino que habían sido quebrantadas en Granada. Los Reyes Católicos reconocían la práctica de la derrota de mieses. Por la segunda, declaraban la existencia de la comunidad de pastos en dicho territorio, frente a quienes pretendían quedar exceptuados de la misma.

Para el marqués de Villadares la ley de 1490 había quedado derogada por otras posteriores favorables a la propiedad, como la de 5 de junio de 1788 y las de 13 de septiembre y 19 de octubre de 1814 . Consideraba que, en virtud de dichas disposiciones, los propietarios podían acotar sus fincas y gozarlas exclusivamente.

La Mesta, en el memorial de 1826, aludía a que la real cédula de 19 de octubre de 1814 permitía a los dueños de predios rústicos la libre disponibilidad y pleno disfrute de sus producciones y el poder cercarlos. Pensaba que esa ley no habría de tener vigencia en Granada, donde los pastos eran comunes, en virtud de la provisión de 1490, que no consideraba derogada. Esta institución no se oponía a que se cercaran los montes y tierras que contuvieran árboles, pero impugnaba la libertad que pretendían tener los propietarios para apropiar los pastos y privar a los ganados de un uso comunal. La aceptación, por parte de la Mesta, de estas cercas suponía, en teoría, un respeto a la legislación que estaba en vigor.

La ley de 1788 trataba de proteger determinados cultivos (olivos, vides, árboles frutales, hortalizas, legumbres) y los nuevos plantíos hechos en heredades de particulares y en los montes de la entrada de los ganados mediante un impedimento jurídico y físico, los cercados. La ley de 1814 establecía la plenitud del disfrute de los propietarios en los montes que les pertenecieran. Su alcance era limitado. Por tanto, sólo en esos terrenos quedaba abolida la comunidad de pastos.

La interpretación de la legislación era, por tanto, errónea.

\section{PRONUNCIAMIENTO DE LAS AUTORIDADES DE LOS MUNICIPIOS GRANADI- NOS SOBRE LOS PASTOS}

El Acuerdo de la Chancillería de Granada determinó que se dirigieran cartas órdenes a los jueces de los pueblos, cabeceras del partido del reino de Granada, para que hicieran conocer el expediente a que dio lugar el memorial del Concejo de la Mesta de 21 de marzo de 1826, a los ayuntamientos de los pueblos de sus respectivos partidos. Además, las autoridades habían de fijar edictos para que llegara noticia de todos los vecinos la pretensión de la Mesta y para 
que cuantos tuvieran interés en los pastos expusieran instructivamente a la Chancillería de Granada lo que estimasen oportuno en el término de quince días. Este tribunal tenia en cuenta la importancia de este asunto para todo el vecindario por ser extensivo a todo el reino de Granada el privilegio de pasto común que el Concejo de la Mesta pretendía que subsistiera.

De 197 pueblos a los que se remitió noticia del expediente, 36 se manifestaron a favor de la comunidad de pastos, 36 en contra (vid. apéndice), 21 nada útil decían en relación a la pregunta que se les formulaba, que parecían no entender, y 104 respondían que quedaban enterados, sin tomar partido ${ }^{66}$.

Muchos pueblos del reino de Granada contaban con términos reducidos, dedicados en su mayor parte a vides, olivos, árboles frutales, cultivos intensivos en regadío y siembras. La derrota de mieses había retrocedido ante el avance de una agricultura intensiva. Las hierbas, según las autoridades municipales, resultaban insuficientes donde los términos eran estrechos y abundantes en tierras de labor y donde la labranza se había expandido al aumentar la población $^{67}$. Con frecuencia los ganados sólo contaban con los pastizales que producían las fincas rústicas de particulares, cuando no estaban sembradas, y los que crecían entre vides y árboles. La concurrencia de reses procedentes de otras jurisdicciones hacía escasear unos pastos por sí exiguos. Ocasionaría un descenso del número de cabezas de ganado existente en cada localidad y de las cosechas, al disminuir el estiércol ${ }^{6}$. Apreciación errónea, la existencia de la comunidad de pastos posibilitaría que los rebaños de un pueblo pastasen en otros y la llegada de los foráneos compensaría el posible descenso de abono.

Algunas corporaciones municipales pensaban que para conservar los montes y repoblarlos era preciso que no hubiese comunidad de pastos. Estos predios constituían, según las autoridades de Gor, una de los principales fuentes de riqueza del reino de Granada. Surtían de leña y carbón a los vecinos, de madera para construir viviendas, aperos de labranza y carros para el transporte, servían

66 Aparece una relación sucinta de estos pueblos en A.H.N., Consejos, legajo 3961, núm. 7, donde se encuentran sus respuestas. La mayoría de éstas son escuetas y poco provechosas. Las más importantes son las procedentes de Alhaurín, Bayarcal, Vélez Málaga, Berchules, Jerez del Marquesado, Dolar, Aldeire, Gor, Diezma, Guadix y Alhama. (He mantenido la ortografía de los pueblos según figura en la fuente).

67 Aurora Gámez Amián (1986), pp. 25-54, en base al análisis de los censos, estima como probable un aumento de población del 62 por ciento entre 1718 y 1797 y una tasa media de crecimiento real acumulativo del 0,52 por ciento. Aumento demográfico que no fue homogéneo, ya que fue más intenso en la periferia que en el interior. La zona centro-oriental fue donde creció más el número de habitantes. La expansión de la vid, a costa de los granos, actuó como foco de absorción de gran cantidad de mano de obra.

Las cosechas fueron más abundantes en el siglo XVIII en el reino de Granada debido a la rotura de tierras. Dominaban los secanos dedicados a cereales. Tuvo lugar una expansión de la vid, el maíz, cáñamo, lino y la entrada de la patata en esta centuria. (Vid. las obras citadas en la nota 45).

68 Motivos a los que aludían las autoridades de Alhaurín, Bayarcal, Aldeire, Alhama, Tiñana, Polopos, Torbiscon, Canillas de Aceytuno, Albuñol, Montejaque, Tregenite, Lujar, Alcazar, Comares. 
de refugio a los ganados en el invierno y les proporcionaban ramón y ramaje cuando nevaba, sin cuyo auxilio perecerían.

La sierra que Alhaurín compartía con Mijas contenía monte bajo que suministraba, según los concejales, leña y esparto al vecindario. Los pobres, sobre todo las mujeres, obtenían un ingreso recolectando el esparto y haciendo cestos en los que recogían los higos, fruto abundante, que vendían en otras poblaciones.

Las leyes del siglo XV, según el síndico personero de la ciudad de Vélez Málaga, se habían expedido por los Reyes Católicos para fomentar la ganadería. Esta era la principal actividad y riqueza que había en el reino de Granada debido a su escasa densidad demográfica con motivo de la guerra de reconquista. Si, en dicha centuria, esa legislación había resultado beneficiosa no lo era en 1827. Granada estaba más poblada y se habían expandido los árboles frutales, las vides y olivos. Era preciso que no entrasen los ganados para que estos cultivos prosperasen.

Los concejales tenían presente que se habían producido cambios apreciables en la demografía y agricultura desde el siglo XV al primer tercio del XIX. La comunidad de pastos había resultado favorable en el siglo XV, pero no en la actualidad. En el siglo XIX el aumento de la población había exigido poner más tierras en cultivo. La expansión del área labrantía a costa de los pastos había provocado la escasez de éstos en algunos lugares. Por ello, y por los demás motivos a los que hemos aludido, eran contrarios a la comunidad de pastos y partidarios de que sólo los ganados de los vecinos y no los de forasteros disfrutasen las hierbas. Incluso había quienes estimaban que los pastos que producían las fincas privadas debían utilizarlos exclusivamente los propietarios o colonos ${ }^{69}$. Eran propicios a que agricultura y ganadería estante se integraran. Condenaban una legislación que estaba favoreciendo en mayor medida a ganados, como los trashumantes, que no se insertaban en la actividad agrícola.

La comunidad de pastos implicaba reciprocidad entre los diversos pueblos en el uso de las hierbas. En teoría, había de favorecer a todos los ganaderos, salvo que existiese una manifiesta desigualdad en su aprovechamiento.

En realidad, ¿a quienes beneficiaba la comunidad de pastos? A grandes ganaderos que, según algunos consistorios, habrían de trashumar a cualquier lugar del reino de Granada con sus rebaños, pero no a los de escasa fortuna que no podrían salir fuera de sus términos. Los ganados de los vecinos acusarían la escasez de hierbas por la entrada en su jurisdicción de los foráneos, en el supuesto de que aquéllos no pudieran desplazarse a otros lugares. Favorecía también a los hermanos de la Mesta, sobre todo a quienes poseían muchas cabezas de ganado, que eran quienes escogían los mejores sitios para paridera, dejando los peores a los pequeños ganaderos. Además unos pocos aprovechaban los pastos de varias localidades ${ }^{70}$.

69 Así lo pedía el síndico personero de Vélez Málaga el 15 de septiembre de 1827.

70 Según los ayuntamientos de Dolar, Aldeire, Gor y Diezma. 
¿Hasta qué punto se observaba la comunidad de pastos?

Algunos ayuntamientos referían que los rebaños de los vecinos eran los únicos que usufructuaban las hierbas que producían sus términos porque esca$\operatorname{seaban}^{71}$.

Los habitantes de Albuñol, según el consistorio, estaban de acuerdo con que cada propietario siguiera gozando de sus haciendas como lo habían hecho hasta 1827. Éstas, recogidos los frutos, eran guardadas por los dueños o las justicias para preservarlas de los ganados. Parece, pues, que aquí no había limitaciones al derecho de propiedad.

Tanto en Vélez Málaga como en Berchules los labriegos reservaban una de las tres hojas en que se dividían las tierras cultivadas para pasto de sus ganados. En Burgo las únicas hierbas que guardaban eran las de los manchones de los cortijos desde San Andrés a Santa Cruz, si habían concluido las barbecheras, y el manchón concejil que, de común acuerdo con los labradores y con aprobación del tribunal superior, designaban todos los años.

En la ciudad de Almería no regía de forma absoluta la comunidad de pastos. El Concejo de la Mesta había interpuesto demanda contra la ciudad alegando que no debía alterar el precio de las hierbas contra sus privilegios. La Chancillería de Granada, por ejecutoria de 1593, determinó que la ciudad podía hacer lo que le conviniera porque los pastos eran de su propiedad. Los capitulares los arrendaban al año a los forasteros. Sólo los habitantes de la ciudad y pueblos de su jurisdicción los aprovechaban gratis por ser comunes para éstos.

El ayuntamiento de Tiñana alegaba el 10 de noviembre de 1827 que habiendo varios pueblos de la Alpujarra interpuesto recurso para disfrutar las hierbas en común con esta villa, les fue denegado.

Las autoridades de otros pueblos manifestaban que los pastos pertenecían a los concejos por haberlos comprado después de la expulsión de los moriscos o con motivo de la venta de baldíos. Los capitulares arrendaban las hierbas sobrantes a los forasteros. Los ingresos que obtenían servían, junto con otros de distinta procedencia, para atender a sus necesidades. Aumentarían la presión fiscal sobre los vecinos si faltaba este recurso ${ }^{72}$.

El limitado número de cabezas de ganado existente en algunos pueblos hacía innecesaria la comunidad de pastos. En otros, las leyes del siglo XV habían quedado invalidadas al estar las hierbas arbitradas o formar parte de los bienes de propios. Como afirmaba la corporación municipal de Trevelez, el 10 de septiembre de 1827, al pueblo le reportaría utilidad que los pastos siguieran como «propios del común de vecinos y no como comunes». Los concejales de Albrucena referían que «la subsistencia de los fondos de sus propios y arbitrios lo más de ello consisten en sus pastos».

71 En Benahaduz, Canfozar, Jubiles, Villanueva de las Torres y Olula de Castro.

72 Era el caso de Canillas de Albaida, Almería, Nechite, Trevelez, Diezma, Guadix, Jerez del Marquesado, Mairena, Abruzena y Poqueira.

Hispania, LXII/3, núm. 212 (2002) 957-992 
Las mismas razones que unos pueblos argumentaban para oponerse a la mancomunidad de pastos eran esgrimidas por otros para pronunciarse a favor. Había ayuntamientos que opinaban que no era aconsejable la llegada de ganados procedentes de otros jurisdicciones por la insuficiencia de hierbas, que se acentuaría. Otros, como Sorvas y Castares, en cambio, estimaban que los pueblos debían tolerar la entrada en sus términos de rebaños ajenos porque los ganados no podrían subsistir si mutuamente no se socorrían debido a la penuria de pastos.

Los concejales de algunos municipios tenían en cuenta la decadencia de la ganadería y la dificultad de su subsistencia debido a la escasa superficie de sus términos, la falta de lluvias, las roturas. La comunidad de pastos posibilitaría el sustento y aumento de los ganados y de las cosechas, al haber mayor disponibilidad de abono y, consiguientemente, según las autoridades de Valor, bajaría el precio de los productos ganaderos y se evitarían las pugnas que habrían de surgir si los pastos se privatizaban ${ }^{73}$.

Para los consistorios de Castares y Cherin la trashumancia del ganado ovino hacía precisa la existencia de pastos comunes.

No obstante, cabe que nos preguntemos por qué estaban descendiendo los rebaños en determinados lugares, como en Arriate, si la comunidad de pastos, según el concejo de la Mesta, existía en todo el reino de Granada. Se debía a la falta de pastizales en determinados pueblos y a la dificultad de llevar las reses a otros más distantes. ¿Qué beneficio reportaba a los vecinos, ganados y labranzas las leyes del siglo XV, cuya subsistencia defendía la Mesta de Granada? Una legislación que había dejado de observarse en muchos pueblos.

La corporación municipal de Galera opinaba que sin la comunidad de pastos que varios pueblos tenían entre sí, además de la general en todo el reino, «no podría prosperar la cría de ganados», dado que el pueblo que carecía de pastos se socorría de los inmediatos. Algunos concejos referían que tenían mancomunidad de pastos con otros de tiempo inmemorial. Era el caso de la villa de Macael con la ciudad de Baza y la villa de Laroya; de Cartama con la ciudad de Málaga y con Pizarra, su arrabal; de Yznate con Vélez Málaga; de Jayena, Arenas del Rey, Jatar, Fornes, Torre de Alhama y lugares de su partido; de los pueblos de Ocaña con los del partido de Tiñana y de éstos con el marquesado de Cenete. Pese a la existencia de estas mancomunidades, Arenas del Rey y Jatar contaban con escaso número de ganados, por lo que éstos no tenían necesidad de salir de sus propios términos.

Los concejales de Periana opinaban que estando en práctica la mancomunidad y disfrute de pastos "por partidos y jurisdicciones", como en el de Vélez Málaga, esto era lo que convenía y no otra cosa. Al consistorio de Terque le

73 Eran los alegatos de las autoridades de pueblos como Sorvas, Ohanes, Valor, Layalonga, Cortijada de Santa Cruz de Alhama, Arriate, Benamocarra, Alquite, Cadiar, Alcolea, Cherin, Narila.

Hispania, LXII/3, núm. 212 (2002) 957-992 
parecía conveniente la comunidad de pastos con todos los pueblos de la tierra de Marchena, "por ser todos un mismo señorío».

\section{EL DICTAMEN DE LOS FISCALES Y LA DECISIÓN DE LOS TRIBUNALES DE JUS- TICIA}

El fiscal del Consejo de Castilla emitió su informe el 31 de julio de 1827. Era partidario de que subsistiera la mancomunidad de pastos en el reino de Granada tal como la establecieron los Reyes Católicos ${ }^{74}$. No debía constituir un impedimento las adquisiciones de terrenos baldíos, concejiles y otros destinados a pasto, sobre los que pesaba «el gravamen» de admitir en ellos los ganados de los vecinos de los pueblos. La mancomunidad de pastos era de absoluta necesidad en el reino de Granada por la escasez de hierbas debido a «su localidad, aspereza y quebrado de su terreno», la extensión de los cultivos hasta las cumbres de la montaña y la falta de lluvias en las inmediaciones de la costa. Permitir los acotamientos ocasionaría perjuicios «al bien público, e interés general». Por ello, se adhería a la solicitud del Concejo de la Mesta.

El Acuerdo de la Chancillería de Granada expresaba el 22 de agosto de 1827 que la demora en evacuar su dictamen no se debía a omisión sino a la indiferencia y falta de eficacia de las personas e instituciones emplazadas en esta audiencia $^{75}$. Hasta el 13 de diciembre de 1828 no emitió su informe. Entonces se mostraba de acuerdo con el parecer del fiscal que conceptuaba «fundado en razones convincentes e innegables», sin perjuicio de lo determinado por la real cédula de 19 de octubre de 1814. Este tribunal opinaba que los privilegios de la Mesta debían observarse en los pastos no acotados legítimamente y en los terrenos no destinado a cría y fomento de toda clase de árboles, donde, para que prevalecieran, debía impedirse la entrada de los ganados. En definitiva, esta institución debía respetar los cercados realizados en virtud de la legislación promulgada.

\footnotetext{
74 Los concejales de localidades del reino de Granada también aludían a la mancomunidad de pastos. Para José M. Mangas Navas (1981) ésta «se establece entre municipios colindantes para el aprovechamiento recíproco de las yerbas en parte o en la totalidad de sus respectivos términos». Se trata de un "sistema de aprovechamientos pecuarios, basado en el convenio, surge para aunar aspiraciones e intereses contrapuestos...», p. 212. No es el caso de lo estipulado por los Reyes Católicos en 1496, pese a que algunos lugares es posible que se encontraran en esta situación. Mencionan también la comunidad de pastos Juan Ossorio Morales (1936), p. 97 y Manuel Cuadrado Iglesias (1980), pp. 428-431.

75 Lo mismo expresa el 12 de noviembre de 1827 Antonio Pérez Valderrama, desde Torviscón. Dice: «son infinitas las torpezas que han mediado en estos pueblos en orden a evacuar lo que se les mandaba, y ellas han dado lugar a la demora». El corregidor de la ciudad de Vélez Málaga y su partido advierte el 8 de enero de 1828 que «la dilación que han ocasionado los pueblos ha motivado el atraso que se nota en este expediente, sin duda porque no alcanzando a este distrito la ganadería trashumante no han creído los pueblos podían tener interés inmediato en el negocio». A.H.N., Consejos, legajo 3961, núm. 7.
} 
Este expediente, como otros de igual naturaleza, corrieron la misma suerte. El Consejo de Castilla determinaba el 9 de junio de 1829 su sobreseimiento hasta que se solventara el general sobre cercados. Así se acordó por real provisión de 28 de julio de 1829 . Por tanto, quedó sin determinar.

El fiscal del Consejo de Castilla aceptaba el 16 de enero de 1834 el fallo de este tribunal. Era partidario de sobreseer este expediente, dada la analogía que tenía con el general de acotamientos, hasta que éste se solucionara. Refería, además, que por decreto de 23 de octubre de 1833 se había creado una Junta para revisar las leyes y reglamentos existentes en relación a acotamientos a fin de discutir y redactar una nueva norma al respecto. Hasta que esto no tuviera lugar no debía introducirse ninguna novedad para evitar providencias que pudieran ser contrarias a la ley que se promulgase sobre cercados y acotamientos.

La resolución de este expediente tendría lugar con el decreto de 6 de septiembre de 1836 que restablecía en "su fuerza y vigor» el de las Cortes de Cádiz de 8 de junio de 1813. Además, ese mismo año se suprimió el Concejo de la Mesta.

\section{CONCLUSIONES}

Había opiniones contrapuestas en el reino de Granada sobre la pertenencia de las hierbas.

Defendía la existencia de los pastos comunes la Mesta del reino de Granada, para quien la legislación del siglo $\mathrm{XV}$ seguía en vigor, por no haber sido expresamente revocada. Por ello, consideraba que los pastos que producían las tierras privadas no eran de sus dueños por ser comunales y quienes integraban esta institución podían usarlos gratis y señalar para paridera los sitios que les conviniesen en virtud de sus ordenanzas.

Tanto los ayuntamientos de la ciudad de Granada como los de algunos pueblos coadyuvaban a la solicitud de la Mesta, teniendo en cuenta la necesidad de que subsistiera la legislación del siglo XV por las condiciones del medio natural que habían hecho precisa la existencia de pastos comunes para el sustento de la ganadería. ¿ Se trata de consistorios dominados por ganaderos de la Mesta municipal a quien interesaba la vigencia de dichas leyes? Lo desconozco.

La férrea defensa de los herbajes comunes por parte de esta institución pudo ser el resultado de la crisis por la que estaba atravesando las explotaciones trashumantes como consecuencia del desplazamiento de las lanas españolas por las sajonas en los mercados externos y la subida de los costes de producción ${ }^{76}$. Estos se incrementarían más si se privatizaban las hierbas y para acceder a ellas los ganaderos tuvieran que tomarlas en arrendamiento.

76 Vid. Ángel García Sanz (1978), pp. 283-356; Enrique Llopis Agelán (1982), pp. 1-102; Luis María Bilbao y Emiliano Fernández de Pinedo (1986), pp. 343-362; Luis María Bilbao (1998), pp. 303-331; Pedro García Martín (1988); Miguel Ángel Melón (1998), pp. 332-363.

Hispania, LXII/3, núm. 212 (2002) 957-992 
Los terratenientes y determinados municipios opinaban que la legislación del reinado de Fernando VII anulaba la de los Reyes Católicos. Los particulares consideraban que los pastos que producían sus tierras les pertenecían y podían disponer de ellos. Algunos concejos aducían haberlos adquirido por haber comprado sus términos tras la expulsión de los moriscos o con motivo de la venta de baldíos. El arrendamiento de las hierbas constituía una de sus fuentes de ingresos, a la que no estaban dispuestos a renunciar.

La defensa de los pastos para uso exclusivo de los dueños o vecinos llevaba implícita evitar la injerencia de los mesteños que las aprovechaban de balde y afirmar, en el caso de los particulares, el derecho individual de la propiedad de la tierra.

Las leyes del siglo XV, como evidenciaban algunos consistorios, beneficiaban a quienes poseían grandes cabezas de ganado que eran quienes podían transterminar y escoger, en el caso de pertenecer a la Mesta, los mejores sitios para paridera. Esas leyes habían dejado, por otra parte, de observarse en algunas localidades ante el avance de la agricultura intensiva, al estar los pastos arbitrados en otros municipios, por la escasez de hierbas en determinados términos que hacía imposible acoger a los rebaños de otras jurisdicciones, la reserva que los labriegos hacían de los pastos que producían sus tierras cuando no estaban sembradas, el pleno derecho que tenían algunos dueños a disfrutar sus heredades, etc.

Tanto el fiscal del Consejo de Castilla como la Chancillería de Granada eran partidarios de la subsistencia de la mancomunidad de pastos, teniendo en cuenta las circunstancias locales, y eran favorables a los privilegios de la Mesta que debían guardarse en tierras no acotadas legalmente y en las no destinadas a plantíos de árboles.

El expediente quedó sin resolver, dado que se estaba ventilando dar una ley sobre cercados. Esta habría de ser la de 6 de septiembre de 1836 que ponía en vigor el decreto de las Cortes de Cádiz de 8 de junio de 1813. Suponía, junto a la abolición de la Mesta, la solución a este debate. 


\section{APÉNDICE}

\section{MUNICIPIOS QUE RECHAZAN LA MANCOMUNIDAD DE PASTOS EN EL REINO DE GRANADA:}

Alhaurín
Berchules
Montejaque
Almería
Canjayar
Paterna
Bayarcal
Laroles
Mairena
Nechite
Pitres
Timar

Trebélez
Portugos
Guadix
Alcudia
Albruzena
Jeréz del Marquesado
Tiñana
Dolar
Lanteira
Torbiscon
Alcazar
Albuñol

Polopos

Tregenite

Lujar

Aldeire

Diezma

Gor

Alhama

Vélez Málaga

Comares

Canillas de Albaida

Periana

Canillas de Aceytuno

\section{MUNICIPIOS QUE DEFIENDEN LA MANCOMUNIDAD DE PASTOS EN EL REINO DE GRANADA:}

Galera
Cártama
Jimena de Libar
Arriate
Sorvas
Ohanes
Beires
Laujar
Picena
Valor
Presidio
Alcolea

Yegen
Mecina Bombaron
Poqueira
Mecina Fondales
Terreirola
Almegijar y Notaez
Castares y Nieles
Narila
Cadiar
Yator
Jorairata
Cojayar
Darrical
Cherin
Darro
Pedro Martínez
Moreda
Benamocarra
Frigiliana
Nerja
Layalonga
Yznate

He mantenido la ortografía de los pueblos según figura en una copia del relator. Granada, 13 de diciembre de 1828. A.H.N., Consejos, legajo 3961, número 7.

\section{FUENTES CITADAS:}

\section{Fuentes manuscritas:}

Archivo Histórico Nacional, Sección de Consejos, legajo 3961, núm. 7.

Archivo de las Cortes. Serie general, legajo 10, expediente núm. 50.

Fuentes bibliográficas y colecciones legislativas:

ACTAS del I Congreso de Historia de Andalucía. Andalucía Medieval, Córdoba, (1978), T. I, II. Alijo Hidalgo, F. (1974), Ordenanzas de Antequera (1531), Málaga.

Hispania, LXII/3, núm. 212 (2002) 957-992 
ARGENTE DEL CASTILLO, Carmen (1991), La ganadería medieval andaluza, siglos XIII-XVI. (Reinos de Jaén y Córdoba), Jaén, 2 ts.

ANTIGUAS Ordenanzas municipales de la ciudad de Ronda y su jurisdicción, mandadas pregonar por el rey Felipe II, año de 1568, Ronda, 1889.

BADOSA COLL, Elisa (1984), «El cercamiento de tierras en Cataluña (1770-1820)», Revista de Historia Económica, año II, núm. 3, pp. 149-162.

BERnAL, Antonio Miguel (1988), Economía e Historia de los latifundios, Madrid.

BERNABE GIL, David (1993), «Una coexistencia conflictiva: municipios realengos y señoríos de su contribución general en la Valencia foral», Revista de Historia Moderna. Anales de la Universidad de Alicante, núm. 12, pp. 11-77.

BILBAO, Luis María y FERNÁNDEZ DE PINEDO, Emiliano (1986), «Exportaciones de lanas, trashumancia y ocupación del espacio en Castilla durante los siglos XVI, XVII y XVIII», en Pedro García Martín y José María Sánchez Benito (comps.), Contribución a la Historia de la trashumancia en España, Madrid, pp. 343-362.

BILBAO, Luis María (1998), «Exportación de lana española y demanda británica en el siglo XVIII», en Felipe Ruiz Martín y Ángel García Sanz (eds.), pp. 303-331.

BishKo Charles Julius (1978), «The Andalusian municipal Mestas in the 14 th-16 th centuries: Administrative and social aspects», Actas del I Congreso de Historia de Andalucía. Andalucía Medieval, T. I, pp. 347-375.

(1982), «Sesenta años después: La Mesta de Julius Klein a la luz de las investigaciones subsiguientes», Historia. Instituciones. Documentos, núm. 8, pp. 1-49.

BOSCH, Mónica, CONGOST, Rosa, GIFRE, Pere (1997), «Los 'bandos'. La lucha por el individualismo agrario en Cataluña. Primeras hipótesis (siglos XVII-XIX)», Noticiario de Historia Agraria, núm. 13, pp. 65-88.

CABRERA MUÑOZ, Emilio (1978), «Usurpación de tierras y abusos señoriales en la sierra cordobesa durante los siglos XIV y XV», Actas del I Congreso de Historia de Andalucía. Andalucía Medieval, T. I, pp. 33-83.

CARDENAS, Francisco de (1873), Historia de la propiedad territorial en España, Madrid.

CARMONA Ruíz, María Antonia (1993), «Ganadería y vías pecuarias del Sur de Extremadura durante la Baja Edad Media», Trasbumancia y cultura pastoril en Extremadura, pp. 51-67.

(1995), Usurpación de tierras y derechos comunales en Sevilla y su tierra durante el siglo XVI, Madrid.

(1998), La ganadería en el reino de Sevilla durante la Baja Edad Media, Sevilla.

CAXA DE LeRUELA, M (1975), Restauración de la abundancia de España, Madrid.

COLECCIÓN DE LOS DECRETOS y órdenes que han expedido las Cortes Generales y Extraordinarias, Madrid, 1820.

COLECCIÓN OFICIAL DE LAS LEYES, reales disposiciones y circulares de interés general expedidas por el rey D. Fernando VII y por las Cortes en el año de 1820 por Juan Muñiz Miranda, Madrid, 1853.

COLECCIÓN DE LAS REALES CEDULAS, decretos y órdenes de S.M. el Señor D. Fernando VII desde 4 de mayo de 1814, Valencia, 1814.

COSTA, Joaquín (1898), Colectivismo agrario en España, Madrid.

CuAdrado Iglesias, Manuel (1980), Aprovechamiento en común de pastos y leñas, Madrid.

Hispania, LXII/3, núm. 212 (2002) 957-992 
Diego HernaNdo, Máximo (1993 a ), «El arrendamiento de pastos en las comunidades de villa y tierra a fines de la Edad Media: una aproximación», Agricultura y Sociedad, núm. 67, pp. 185-204.

(1993 b), Soria en la Baja Edad Media: espacio rural y economía agraria. Madrid.

(1994), «El aprovechamiento de pastos de verano en las comarcas ganaderas del Sistema Ibérico castellano en los siglos XV y XVI», Noticiario de Historia Agraria, núm. 8, pp. 43-66.

FERNÁNDEZ-DAZA ALVEAR, Carmen (1993), «La actividad ganadera en Trujillo durante la Edad Media», Trashumancia y cultura pastoril en Extremadura, pp. 89-106.

FERNÁNDEZ OTAL, José Antonio (1993), La casa de ganaderos de Zaragoza. Derecho y trasbumancia a finales del siglo $\mathrm{XV}$, Zaragoza.

FONTANA, Josep y GARRABOU, Ramón (1986), Guerra y Hacienda. La hacienda del gobierno central en los años de la guerra de la independencia (1808-1814), Alicante, pp. 107-186.

GÁmeZ AMIÁN, Aurora (1986), Transformaciones Económicas y Sociales en el Reino de Granada, siglo XVIII, Málaga.

(1989), «¿Una o varias agriculturas en la Andalucía del siglo XVIII?», en Estructuras agrarias y reformismo ilustrado en la España del siglo XVIII, Madrid, pp. 79-98.

GARCíA DE CORTÁZAR y otros (1985), Organización social del espacio en la España Medieval. La Corona de Castilla en los siglos VIII al XV, Barcelona.

Garcia Fernandez, Jesús (1963), Aspectos del paisaje agrario en Castilla la Vieja, Valladolid.

(1965), "Champs ouverts et champs clôturés en Vieille Castille», Annales. Economies. Sociétés. Civilisations, núm. 4, pp. 692-718.

(1966), «Campos abiertos y campos cercados en Castilla la Vieja». Homenaje al Excmo. Sr. D. Amando Melón y Ruíz de Gordejuela, Zaragoza, pp. 117-131.

GARCía MARTín, Pedro (1988), La ganadería mesteña en la España borbónica (1700-1836), Madrid.

GARCía SÁNZ, Ángel (1978), «La agonía de la Mesta y el hundimiento de las exportaciones laneras: un capítulo de la crisis económica del Antiguo Régimen en España», Agricultura y Sociedad, núm. 6, pp. 283-356.

(1980), «Bienes y derechos comunales y el proceso de su privatización en Castilla durante los siglos XVI y XVII: el caso de tierras de Segovia", Hispania, XL, pp. 95-127.

(1985), «Crisis de la agricultura tradicional y revolución liberal (1800-1850)», en Ángel García Sanz y Ramón Garrabou (eds.), Historia agraria de la España Contemporánea. 1. Cambio social y nuevas formas de propiedad (1800-1850), Barcelona, pp. 7-99

(1998), «Los privilegios mesteños en el tiempo, 1273-1836: una revisión de la obra de Julius Klein», en Felipe Ruiz Martín y Ángel García Sanz (eds.), pp. 65-89.

GARCía SÁNZ, Ángel y SÁNZ FERNÁNDEZ, Jesús (1988), "Agricultura y ganadería», en Miguel Artola (dir.), Enciclopedia de Historia de España. I. Economía y Sociedad, Madrid.

GONZÁLEZ JIMÉNEZ, Manuel (1978), «La hermandad entre Sevilla y Carmona (siglos XIIIXIV)», Actas del I Congreso de Historia de Andalucia. Andalucia Medieval, T. II, pp. 3-20.

(1981), «De nuevo sobre las mestas municipales andaluzas: el libro de Mesta de Carmona (1514-1516)». Axerquia, núm. 3, pp. 99-145.

Hispania, LXII/3, núm. 212 (2002) 957-992 
GONZÁLEZ DE LINARES, Gervasio (1902), «Costumbres municipales del Antiguo Régimen», en Joaquín Costa, Derecho consuetudinario y economía popular de España, Barcelona, t. II, pp. 405-431.

KLEIN, Julius (1981), La Mesta. Estudio de bistoria económica española, 1273-1836, Madrid.

LADERO QUESADA, Miguel Ángel (1976), «Donadíos en Sevilla. Algunas notas sobre el régimen de la tierra hacia 1500», Archivo Hispalense, núm. 181, pp. 19-91.

LAGE, José (ed.) (1977), Gaspar Melchor de Jovellanos. Espectáculos y diversiones públicas. Informe sobre la Ley Agraria, Madrid, pp. 147-332.

LÓPEZ DE COCA, José Enrique (1985), «El reino de Granada», en J. A, García de Cortázar y otros, Organización social del espacio en la España Medieval. La Corona de Castilla en los siglos VIII al XV, Barcelona, pp. 195-240.

LÓPEZ-SALAZAR, Jerónimo (1986), Estructuras agrarias y sociedad rural en la Mancha (siglos XVI-XVII), Ciudad Real.

(1987), Mesta, pastos y conflictos en el campo de Calatrava (siglo XVI), Madrid.

LLOPIS AGELÁN, Enrique (1980), «Crisis y recuperación de las explotaciones trashumantes: la cabaña del monasterio de Guadalulpe (1597-1679)», Investigaciones Económicas, núm. 13.

(1982), «Las explotaciones trashumantes en el siglo XVIII y primer tercio del XIX: la cabaña del Monasterio de Guadalupe, 1709-1835», en Gonzalo Anes Álvarez (ed.), La economía española al final del Antiguo Régimen. I. Agricultura, Madrid.

(1986), «El agro castellano en el siglo XVII: ¿Depresión o «reajustes y readaptaciones»?», Revista de Historia Económica, año IV, núm. 1, pp. 11-37.

(1998), «Medio siglo de una gran explotación trashumante: la cabaña merina del Monasterio de El Paular, 1680-1730», en Felipe Ruíz Martín y Ángel García Sanz (eds.), pp. 144-197.

MANGAS NAVAS, José M. (1981), El régimen comunal agrario de los concejos de Castilla, Madrid.

MARÍN BARRIGUETE, Fermín (1987), La Mesta en los siglos XVI y XVII: roturaciones de pastos, cañadas, arrendamientos e impedimentos de paso y pasto, Madrid. Editorial de la Universidad Complutense, 3 ts.

(1992), "Legislación y Mesta: los reinados de Felipe V y Fernando VI». Boletín de la Real Academia de la Historia, t. 189, cuaderno 1, pp. 127-150.

(1994), «La configuración institucional del Honrado Concejo de la Mesta: los Reyes Católicos y los privilegios ganaderos", en Gonzalo Anes y Ángel García Sanz (coord.), Mesta, trashumancia y vida pastoril, Valladolid, pp. 67-89.

(1998), «El derecho de posesión y la lucha por los pastizales, siglos XVI y XVII», en Felipe Ruiz Martín y Ángel García Sanz (eds.), pp. 90-143.

MELÓN JimÉNEZ, Miguel Ángel (1998), «Mercado lanero y capital comercial en Extremadura a finales del Antiguo Régimen, 1773-1836», en Felipe Ruiz Martín y Ángel García Sanz (eds.), pp. 332-363.

MINGUEZ FERNÁNDEZ, José María (1982), "Ganadería, aristocracia y reconquista en la Edad Media castellana», Hispania, XLII, pp. 341-354.

MILlÁN, Jesús (1984), Rentistas y campesinos. Desarrollo agrario y tradicionalismo político en el sur del País Valenciano, 1680-1840, Alicante. 
NIETO, Alejandro (1959), Ordenación de pastos, hierbas y rastrojeras, Valladolid.

NOVÍSIMA RECOPILACIÓN DE LAS LEYES DE ESPAÑA mandada formar por el Señor D. Carlos IV, Madrid, 1976.

OSSORIO MORALES (1936), Las servidumbres personales, Madrid.

PÉREZ CEBADA, Juan Diego (2001), "Cerramientos y gran propiedad. Jerez de la Frontera, siglos XIII-XVIII, comunicación presentada al Simposio sobre formación y gestión de los grandes patrimonios en España y América Latina (siglos $X V$-XX), celebrado en Valladolid los días 2 y 3 de marzo.

PÉREZ ROMERO, Emilio (1995), Patrimonios comunales. Ganadería trashumante y sociedad en la Tierra de Soria. Siglos XVIII-XIX, Salamanca.

(1996), «Trashumancia y pastos de agostadero en las sierras sorianas durante el siglo XVIII», Revista de Historia Económica, año XIV, núm. 1, pp. 91-124.

(1998), «La trashumancia y sus repercusiones económicas y sociales en zonas de agostadero: el caso de la tierra de Soria en el siglo XVIII», en Felipe Ruíz Martín y Ángel García Sanz (eds.), pp. 198-230.

(1999), «La trashumancia desde las sierras sorianas: la hegemonia de las grandes cabañas», en Miguel Ángel Melón, A. Rodríguez Grajera, A. Pérez Díaz (coords.), Extremadura y la trasbumancia (siglos XVI-XX), Mérida, pp. 35-54.

Peris Albentosa, Tomás (1989), Propiedad y cambio social. Alzira, 1465-1768, Valencia, pp. 34-38.

RAmOS IbASeTA, José Ramón (1988), Política ganadera de los Reyes Católicos en el obispado de Málaga, Málaga.

RODRíGUEZ BLANCO, Daniel (1993), «Ganados y señores en la Extremadura Medieval», Trasbumancia y cultura pastoril en Extremadura, pp. 69-88.

RUFO ISERN, Pauline (1997), «Usurpación de tierras y derechos comunales en Écija durante el reinado de los Reyes Católicos: la actuación de los jueces de término», Historia. Instituciones. Documentos, núm. 24, pp. 465-512.

RUíz MARTín, Felipe y GARCía SANZ, Ángel (eds.), (1998), Mesta, trasbumancia y lana en la España Moderna, Barcelona.

SÁNCHEZ SALAZAR, Felipa (1986), Extensión de cultivos en España en el siglo XVIII, Madrid, Servicio de Reprografía de la Universidad Complutense, 2 ts.

(1988), Extensión de cultivos en España en el siglo XVIII, Madrid.

(2001), «Tensiones sociales en el reino de Granada a finales del Antiguo Régimen: la Mesta contra propietarios de tierras y concejos con motivo de los cercados», comunicación presentada al VII Congreso de Historia Económica celebrado en Zaragoza del 19 al 21 de septiembre.

(2002), «Cercados y acotamientos de tierras en Extremadura: la real cédula de 15 de junio de 1788", comunicación presentada al X Congreso de Historia Agraria que tuvo lugar en Sitges del 23 al 25 de enero.

SERNET, Jean (1956), La España del Sur, Barcelona.

SUÁREZ FERNÁNDEZ, Luís (1951), «Evolución histórica de las hermandades castellanas», Cuadernos de Historia de España, núm. 16, pp. 5-57.

Hispania, LXII/3, núm. 212 (2002) 957-992 
TRASHUMANCIA y cultura pastoril en Extremadura. Actas del Simposio celebrado en el pabellón de Extremadura en la exposición universal de Sevilla, 28, 29 y 30 de septiembre de 1992, Mérida, 1993.

VASSBERG, David E. (1978), « El campesinado castellano frente al sistema comunitario: usurpación de tierras concejiles y baldías durante el siglo XVI», Boletín de la Real Academía de la Historia, núm. CLXXV, pp. 145-167.

(1983), La venta de tierras baldías. El comunitarismo agrario y la Corona de Castilla durante el siglo XVI, Madrid. 